\title{
A comprehensive review of COVID-19 biology, diagnostics, therapeutics, and disease impacting the central nervous system
}

\author{
Anastasia Williams $^{1} \cdot$ Heather Branscome ${ }^{1,2}$. Pooja Khatkar ${ }^{1}$. Gifty A. Mensah ${ }^{1}$. Sarah Al Sharif ${ }^{1}$. Daniel O. Pinto ${ }^{1,3}$. \\ Catherine DeMarino ${ }^{1} \cdot$ Fatah Kashanchi ${ }^{1}$ [D
}

Received: 11 February 2021 / Revised: 17 May 2021 / Accepted: 1 July 2021 / Published online: 28 September 2021

(c) Journal of NeuroVirology, Inc. 2021

\begin{abstract}
The ongoing COVID-19 pandemic, caused by severe acute respiratory syndrome coronavirus 2 (SARS-CoV-2), is a highly transmissible disease. SARS-CoV-2 is estimated to have infected over 153 million people and to have caused over 3.2 million global deaths since its emergence in December 2019. SARS-CoV-2 is the seventh coronavirus known to infect humans, and like other coronaviruses, SARS-CoV-2 infection is characterized by a variety of symptoms including general flu-like symptoms such as a fever, sore throat, fatigue, and shortness of breath. Severe cases often display signs of pneumonia, lymphopenia, acute kidney injury, cardiac injury, cytokine storms, lung damage, acute respiratory distress syndrome (ARDS), multiple organ failure, sepsis, and death. There is evidence that around 30\% of COVID-19 cases have central nervous system (CNS) or peripheral nervous system (PNS) symptoms along with or in the absence of the previously mentioned symptoms. In cases of CNS/PNS impairments, patients display dizziness, ataxia, seizure, nerve pain, and loss of taste and/or smell. This review highlights the neurological implications of SARS-CoV-2 and provides a comprehensive summary of the research done on SARS-CoV-2 pathology, diagnosis, therapeutics, and vaccines up to May 5.
\end{abstract}

Keywords SARS-CoV-2 $\cdot$ COVID-19 $\cdot$ Coronavirus $\cdot$ CNS

\section{Introduction}

In December 2019, a novel coronavirus was discovered in Wuhan China. Initially designated as 2019-nCoV by the World Health Organization (WHO) on January 12, 2020, this virus became the latest entrant in the family of coronaviruses able to infect humans (WHO 2020a). On February 11,2020 , the virus was renamed severe acute respiratory syndrome coronavirus 2 (SARS-CoV-2) by the International Committee on Taxonomy of Viruses (ICTV), and the WHO subsequently named the disease caused by SARS-CoV-2 as coronavirus disease 2019 (COVID-19) (Coronaviridae

Fatah Kashanchi

fkashanc@gmu.edu

1 Laboratory of Molecular Virology, School of Systems Biology, George Mason University, Manassas, VA, USA

2 American Type Culture Collection (ATCC), Manassas, VA, USA

3 Immunology Core, Malaria Biologics Branch, Walter Reed Army Institute of Research, Silver Spring, MD, USA
Study Group of the ICTV 2020; WHO 2020a). Having been declared as the sixth public health emergency of international concern (after H1N1, polio, Ebola (West Africa), Zika, and Ebola (Democratic Republic of Congo)) by the WHO, the resulting outbreak of COVID-19 has caused a pandemic that has accelerated at an unprecedented scale (Lai et al. 2020). As of May 2021, there are an estimated 153 million reported cases and over 3.2 million global deaths associated with COVID-19, with numbers continuing to rise daily (WHO 2021).

Coronaviruses are enveloped viruses that contain a positivesense, single-stranded RNA genome approximately $30 \mathrm{~kb}$ in size (Fehr and Perlman 2015). Briefly, coronaviruses belong to the Coronaviridae family of the Nidovirales order. Coronaviridae is divided into the two subfamilies Torovirinae and Coronavirinae, the latter of which is categorized into four genera including Alphacoronaviruses, Betacoronaviruses, Gammacoronaviruses, and Deltacoronaviruses (Pal et al. 2020). SARS-CoV-2, specifically, is classified in the betacronavirus genera. Previous human betacoronaviruses have caused epidemics, namely severe acute respiratory syndrome (SARS) in 2002 and Middle East respiratory 
syndrome (MERS) in 2012, but SARS-CoV-2 has a greater transmission rate, albeit lower mortality (Liu et al. 2020; Petrosillo et al. 2020). To underscore this point, the basic reproduction number $\left(\mathrm{R}_{0}\right)$, which is a key epidemiologic metric used to indicate the transmission potential of an infectious agent, has been estimated to range between 2 and 3 for SARS-CoV-2 (Delamater et al. 2019; Lai et al. 2020; Salzberger et al. 2020). For reference, SARS had an associated $\mathrm{R}_{0}$ of approximately 1.7 to 1.9 while the $\mathrm{R}_{0}$ associated with MERS was reported to be $<1$ (Petrosillo et al. 2020). The high transmission rate of SARS-CoV-2 may be the cause of the higher viral loads that have been observed during early infection (Hu et al. 2020; Wölfel et al. 2020; Zou et al. 2020). Moreover, it has been suggested that asymptomatic carriers of SARS-CoV-2, which in some cases have ranged from 18 to $81 \%$, have largely contributed to the spread of the pandemic (Nikolai et al. 2020).

With the emergence of SARS-CoV-2, there are now a total of seven coronaviruses which can infect humans. As previously mentioned, the zoonotic betacoronavirus SARS$\mathrm{CoV}-1$ resulted in the SARS epidemic that first emerged in Southern China in November 2002. At the time of the last documented case in 2003, the virus had spread to 27 countries and had resulted in approximately 8000 probable cases with a mortality rate of $\sim 10 \%$ (Cherry 2004; Perlman and Netland 2009). Similarly, in two separate incidents in 2012 and 2015, MERS-CoV was responsible for MERS outbreaks originating in Saudi Arabia and South Korea, respectively. To date, MERS is still considered an endemic disease in many Middle Eastern countries and there have been 2,500 confirmed cases with an associated fatality rate of $~ 35 \%$ (Chafekar and Fielding 2018; Willman et al. 2019).

Evidence suggests that the evolutionary origins of both SARS-CoV-1 and MERS-CoV involved bats and later adapted to intermediate hosts such as civets and camels, respectively, prior to humans (Corman et al. 2014). This information suggests that bats could be the natural reservoir for SARS-CoV-2; however, the intermediate host(s) have yet to be confirmed (Wu et al. 2020; Zhao et al. 2020; Zhou et al. 2020). Along these lines, the phylogenetic analysis from a recently published article showed that SARS-CoV-2 shares $88.1 \%$ identity to two bat-derived SARS-like coronaviruses (bat-SL-CoVZC45, bat-SL-CoVZXC21), whereas only $79 \%$ and 50\% homology was shared with SARS-CoV-1 and MERS-CoV, respectively ( $\mathrm{Lu}$ et al. 2020; Wu et al. 2020; Zhou et al. 2020). Another recent report has studied the interactions between the SARS-CoV-2 spike protein receptor binding domain (RBD) and the host receptor ACE2, revealing that pangolins, snakes, and turtles may also serve as potential intermediate hosts of SARS-CoV-2 (Liu et al. 2020).

Like other human coronaviruses (e.g., 229E, OC43, NL63, HRU1), SARS-CoV-2 infection is characterized by symptoms similar to those of the common cold including fever, cough, fatigue, sore throat, and shortness of breath (Guan et al. 2020; Kumar et al. 2020; Su et al. 2016). In critical cases, patients often develop pneumonia, lymphopenia, acute kidney injury, and cardiac injury (Huang et al. 2020). The most severe cases of COVID-19 are associated with an over-activation of the immune system which can induce a cytokine storm. In the absence of therapeutic intervention, this can lead to significant pulmonary inflammation and extensive lung damage, acute respiratory distress syndrome (ARDS), secondary infection, multi-organ failure, deep venous thrombosis, and sepsis, all of which may ultimately result in death (Hojyo et al. 2020; Tang et al. 2020; Wichmann et al. 2020). Although the respiratory system is the primary target of SARS-CoV-2, it is also becoming clear that the virus may also drive dysfunction and pathology in the central nervous system (CNS). Previous reports have suggested that up to $30 \%$ of patients infected with SARSCoV-2 suffered from neurological symptoms such as dizziness, ataxia, seizure, nerve pain, encephalitis, and impairments relating to vision, taste, and smell (Ellul et al. 2020; Li et al. 2020; Mao et al. 2020).

Since its emergence, SARS-CoV-2 has caused a significant public health crisis that has left a crippling effect not only on the medical system, but also across numerous socio-economic platforms (Ceylan et al. 2020). Thus, if left unchecked, SARS-CoV-2 could pose the greatest healthcare challenge of the century. At the time of this article, there are three FDA emergency use authorization (EUA)-approved vaccines available in the USA and a few others throughout the world. Therapeutic options currently center around preventive measures and supportive care. This review will highlight the current knowledge surrounding the biology, diagnostics, and therapeutic options relating to COVID19. A special emphasis will also be placed on discussing the implications and potential long-term complications of SARS-CoV-2 in the context of the CNS.

\section{COVID-19 pathology}

COVID-19 is caused by the single-stranded, positive-sense RNA virus SARS-CoV-2. Its highly contagious nature, coupled with the large proportion of asymptomatic transmitters, has significantly contributed to the rapid spread of COVID19. However, since the onset of the outbreak, substantial progress has been made in the understanding of SARS-CoV-2 transmission. This has led to the implementation of certain measures to decrease its spread. While it is widely accepted that respiratory transmission (via respiratory droplets) is the primary route of transmission, other modes of transmission such as fomites, domestic pets/farm animals, fecal, aerosol, 
sexual, and bloodborne transmission cannot be conclusively ruled out at this time (Meyerowitz et al. 2020).

After exposure to the virus, symptoms typically manifest after an incubation period of 5 to 6 days; however, incubation periods of up to 14 days have also been reported (Guo et al. 2020; Shanmugam et al. 2020). It is also worth noting that in older adults, symptoms may be more severe and are often further complicated in individuals with comorbidities and other medical conditions (e.g., asthma, chronic obstructive pulmonary disease, cardiovascular disease, hypertension, diabetes) (Ahn et al. 2020; Wolff et al. 2020). Although the virus establishes infection primarily in the respiratory tract, it has also become widely appreciated that the virus can drive pathology outside of the lungs, including in the digestive tract, the circulatory system, and the central nervous system (Zhang et al. 2020).

Similar to SARS-CoV-1, SARS-CoV-2 primarily utilizes the host cellular receptor angiotensin-converting enzyme 2 (ACE2) to enter host cells and establish infection (Zhou et al. 2020). Briefly, the mechanisms of viral attachment and cell entry are mediated by the spike (S) protein located on the surface of the virus. The $\mathrm{S}$ protein directly associates with the ACE2 receptor via its receptor-binding motif (RBM) (Weiss and Leibowitz 2011). This is followed by membrane fusion and the release of viral RNA (Guo et al. 2020). ACE2 is mainly found on lung alveolar epithelial cells as well as small intestine enterocytes, which could explain the lower respiratory and gastrointestinal symptoms experienced by some SARS-CoV-2 patients, as well as explain the tropism of SARS-CoV-2's abundant replication in the upper respiratory epithelia (Guo et al. 2020; Wiener et al. 2007; Xu et al. 2020; V'kovski et al. 2021; Zhang et al. 2020). However, broad distribution of the ACE2 receptor has also been reported by others who have found varying levels of ACE2 mRNA or protein expression in distinct cell types (e.g., vascular endothelial and smooth muscle) and tissues (heart, kidney, thyroid, liver, colon, bladder, and brain) (Dong et al. 2020; Hamming et al. 2004; Li et al. 2020; Zou et al. 2020). Additionally, there is evidence of ACE2 expression in glial cells and neurons within the brain and upregulated on activated type 1 macrophages (M1) and on tissue-specific macrophages (Baig et al. 2020; Panariello et al. 2020; Song et al. 2020).

The ACE2 receptor has multiple potential functions during infection with SARS-CoV-1 or SARS-CoV-2, which may include the following: to mediate viral entry, initiate intracellular inflammation, and induce shedding of the ACE2 receptor. Shedding of the ACE2 ectodomain, or the downregulation of ACE2, was found to be coupled with tumor necrosis factor- $\alpha$ (TNF- $\alpha$ ) activation, a trait associated with severe cases of SARS-CoV-1 infection (Haga et al. 2008). Increased levels of TNF- $\alpha$ could contribute to inflammation and subsequent tissue damage, increasing the severity of the infection. Altogether, these effects may further facilitate viral spread.

Studies have shown that SARS-CoV-2 may use a variety of host proteins to enter cells as well as ACE2. The SARSCoV-2 $\mathrm{S}$ protein is a homotrimer, each consisting of two subunits, S1 and S2 (Silva-Filho et al. 2020). The S1 subunit is further broken down into two parts S1A (n-terminal domain, NTD) and S1B (receptor binding domain, RBD). ACE2 is proposed to bind with the RBD while sialic acid containing glycoproteins like CD147 is proposed to bind to the NTD (Silva-Filho et al. 2020). For ACE2 binding, transmembrane proteins such as transmembrane protease serine 2 (TMPRSS2) and Cathepsin-L are important for the cleavage of the SARS-CoV-2 spike protein to facilitate host cell membrane fusion and for viral infectivity (Kumar et al. 2020).

Another proposed receptor for SARS-CoV-2 infection is type II transmembrane ectopeptidase protein dipeptidyl peptidase IV (DPP4; also known as CD26). DPP4 has been found enriched in the bronchiolar and alveolar epithelia of the lower respiratory tract, liver, and immune cells of MERS cases; and studies have found high levels of DPP4 and CD147 in SARS-CoV-2-infected cortical cells that had low ACE2 expression (Andrews et al. 2021; Boonacker and Van Noorden 2003; Chan et al. 2013; Hocke et al. 2013; Mattern et al. 1991; Meyerholz et al. 2016; Raj et al. 2013; Widagdo et al. 2019). Furthermore, Andrews et al. discovered a $30 \%$ reduction of SARS-CoV- $2 \mathrm{~N}$ protein and a $70 \%$ reduction of a stress indicating gene, ARCN1, in astrocytes treated with a DPP4 inhibitor (Vidagliptin) compared to untreated cells, thus, indicating a potential SARS-CoV-2 tropism for cells with DPP4 (Andrews et al. 2021).

In addition to ACE2 and DPP4, there may be other receptors used by coronaviruses. For instance, GRP78 has been suggested as a possible secondary receptor for SARSCoV-2; and research has demonstrated five peptides that bind to both the virus Spike protein and the host GRP78 binding sites to prevent viral entry (Allam et al. 2020). Furthermore, SARS-CoV-1 infection has been detected in cells that lack expression of ACE2 receptors, such as in hepatocytes, and cells that naturally express low levels of ACE2 and DPP4, such as those in the CNS, suggesting a potential role of unknown host factors in viral entry and infection (Bernstein et al. 2018; Li et al. 2020; To et al. 2004). In addition, not all ACE2 expressing human endothelial and intestinal cells become infected by SARS-CoV-1 (Chan et al. 2004; Ding et al. 2003).

To better understand the mechanics of SARS-CoV-2 infection (such as important host receptors), in vitro experiments are crucial. Researchers use a variety of cells such as human airway epithelial cells, brain microvascular endothelial cells, and immortal cell lines such as Vero E6 cells to mimic SARS-CoV-2 replication (Jiao et al. 2021; Takayama 2020). Furthermore, there is an increased interest in 
lab grown organoids used to replicate cell systems, such as 3D brain models and human lung organoids (Ramani et al. 2020; Takayama 2020). To further understand the mechanisms of viral spread in SARS-CoV-2, it may be important to, initially, consider the symptomology of COVID-19 patients along with in vitro studies to determine preferentially infected systems (e.g., lungs, intestines, or CNS). These observations may eventually lead to the discovery of additional host-related factors.

\section{Lung pathology}

Earlier studies of SARS-CoV-1 reported that downregulation of the ACE2 receptor was associated with viral entry, specifically due to the interaction between the cytoplasmic domain of ACE2 and the S protein of SARS-CoV-1 (Haga et al. 2008; Kuba et al. 2005). The consequences of this deregulation are believed to be linked to intracellular inflammation and deterioration of pulmonary health in SARS-CoV-1-infected patients (Imai et al. 2005). ACE2 has been identified as a key enzyme in the regulation of inflammation related to hypertrophy, pulmonary hypertension, glomerulonephritis, lung injury, sepsis, and acute pancreatitis (Gaddam et al. 2014). ACE2, as well as DPP4, is predominantly expressed by cells of the respiratory tract. Therefore, it is important to examine the relationship between SARS-CoV-1 infection, viral entry via the ACE2/DPP4 receptors, and the associated inflammatory response in infected patients.

As mentioned above, the SARS-CoV-1 S protein induces pleiotropic effects when interacting with the recipient cell. It has been reported that binding of the $S$ protein induces a TNF- $\alpha$-converting-enzyme (TACE)-mediated loss of the ectodomain (extracellular) of the ACE2 receptor and increased production of TNF- $\alpha$ in Vero E6 cells (Haga et al. 2008). Deletion of the carboxyl-terminal domain (cytoplasmic tail) of the ACE2 receptor or through the use of small interfering RNA (siRNA) against TACE decreased viral infection, indicating the importance of the cytoplasmic domain and TACE to viral entry (Haga et al. 2008). A recent study has shown SARS-CoV-2 S protein shares 76\% of its primary sequence with SARS-CoV-1 S protein and it is thought that SARS-CoV-2 induces a similar affect (Ou et al. 2020; Saponaro et al. 2020).

Both SARS-CoV-1 and SARS-CoV-2 are characterized by viral spread through the respiratory tract and potential transmission from person-to-person via droplets, respiratory secretions, aerosols, and direct contact (Guo et al. 2020). The lungs are among the most susceptible organs during SARS-CoV-1 and SARS-CoV-2 infection, with early signs of pneumonia in many patients ( $\mathrm{Gu}$ et al. 2005; Huang et al. 2020; Weiss et al. 2011). The primary cell types of the alveolar walls of the lungs consist of alveolar type I and II epithelial cells (pneumocytes) and alveolar macrophages
(Gralinski and Baric 2015). However, others have reported that only type II pneumocytes, which produce pulmonary surfactant and regulate alveolar surface tension in the lungs, express ACE2 (Bombardini and Picano 2020). As such, it is not surprising that SARS-CoV-1 targets type II pneumocytes, thereby inducing the production of inflammatory cytokines and decreasing surfactant levels (Gralinski and Baric 2015). Therefore, type II pneumocytes expressing ACE2 may represent a key cell type potentially involved in early stages of SARS-CoV-2 infection via oral/nasal routes (Bombardini and Picano 2020; Hoffmann et al. 2020; Uhal et al. 2011; Wiener et al. 2007).

Interestingly, prior observations of patients infected with SARS-CoV-1 described lung pathologies consistent with scattered alveolar damage, unlike other human coronaviruses, and a tropism towards pneumocytes as confirmed by the presence of viral RNA (To et al. 2004). Furthermore, pulmonary pathological examinations of both SARS-CoV-1 and SARS-CoV-2 patients showed pneumocyte hyperplasia (i.e., atypical proliferation of pneumocytes) (Tian et al. 2020; Weiss and Leibowitz 2011). Notably, this pathological transformation marked early phases of infection as patients had not yet developed clinical symptoms (Tian et al. 2020). This implicates pneumocytes as one of the potential primary targets of SARS-CoV-2 infection. Chest computed tomography (CT) scans of COVID-19 patients have also shown abnormalities. For instance, chest CT scans in a cohort of 41 hospitalized patients revealed pneumonia in all patients, with bilateral involvement in $98 \%$ of patients; bilateral, multiple-lobular, and subsegmental areas of consolidation in intensive care unit (ICU) patients; and bilateral ground-glass opacity in non-ICU patients (Huang et al. 2020). These indicators are similar to those of SARS-CoV-1 and MERS-CoV infections and further support the potential susceptibility of pneumocytes to SARS-CoV-2 (Huang et al. 2020).

\section{Systemic inflammation}

SARS-CoV-2 infection has been linked to elevated cytokine levels in patients contributing to cytokine storms, especially in cases of severe COVID-19. The most commonly detected cytokines in the plasma of COVID-19 patients include a wide range of proinflammatory cytokines, such as IL1 $\beta$, IL6, IL12, CXCL10, IL2, IFN $\gamma$, and monocyte chemoattractant protein (MCP1) (Guo et al. 2020; Huang et al. 2020; Xiong et al. 2020). Additionally, Huang et al. noted that plasma samples obtained from ICU patients exhibited higher levels of macrophage-secreting cytokines/chemokines, including granulocyte colony-stimulating factor (GCSF), $10 \mathrm{kD}$ interferon-gamma-induced protein (IP10), MCP1, macrophage inflammatory protein $1-\alpha$ (MIP1 $\alpha$ ), and TNF- $\alpha$ compared to non-ICU patients, thus pointing towards the potential role of cytokines in the severity of infection (Huang et al. 
2020). As such, corticosteroids, routinely used to suppress inflammation, have been used in the treatment regimen of patients infected with SARS-CoV-1 or SARS-CoV-2, targeting cytokine-producing cells (e.g., endothelial cells and macrophages), reducing proinflammatory cytokine levels, and mitigating inflammatory-induced lung injury (Huang et al. 2020; Wang et al. 2020).

In addition to the aforementioned cytokines, patients suffering from severe infection with SARS-CoV-1, MERS$\mathrm{CoV}$, or SARS-CoV-2 have been reported to have high-levels of serum chemokines such as CXL9 and IL8, which may lead to the induction of a cytokine storm (Liu et al. 2020). These groups of chemokines are typically produced by monocytes/macrophages and endothelial cells and are synergistically enhanced in the presence of TNF- $\alpha$, thereby leading to systemic inflammation (Tokunaga et al. 2018). For instance, transient changes in the expression of cytokines and chemokines, such as the early induction of CXCL10 and IL2, and overexpression of IL6 have been found to play a role in the immunopathological response that results in lung injury in SARS-CoV-1 infection (Chien et al. 2006; Liu et al. 2020). Furthermore, the delayed expression of type I interferon (IFN) associated with SARS-CoV-1, in conjunction with strong viral replication, stimulates the accumulation of pathogenic inflammatory monocyte-macrophages and leads to increased concentrations of cytokines/chemokines in the lungs, virus leakage, and diminished virus-specific $\mathrm{T}$ cell responses (Channappanavar et al. 2016). Overall, an increased production of proinflammatory cytokines has been observed in both SARS-CoV-1 and SARS-CoV-2, suggesting a significant role of proinflammatory cytokines, chemokines, and immune cells (e.g., macrophages) in the advancement and severity of the infection (Channappanavar et al. 2016; Liu et al. 2020).

Autopsy results of SARS-CoV-1 patients have shown lung injury demonstrated by diffuse alveolar damage, organizing pneumonia, squamous metaplasia, and bronchiolitis obliterans at later stages of infection, while the lungs of individuals that succumbed to the infection in the early stages featured a loss of pneumocytes, edema, hyaline membranes, small vessel thrombi, lymphocytes, macrophages, and polymorphonuclear leukocytes in the lungs (Liu et al. 2020; Weiss and Leibowitz 2011). Similar lung injury attributed to cytokine storm in the lower respiratory tract was also reported in the deceased bodies of COVID-19 patients (Guo et al. 2020). The consistent manifestation of cytokine storms in multiple severe COVID-19 cases led to the investigation of drugs used to treat malaria, such as chloroquine, due to their ability to suppress the production of proinflammatory cytokines (i.e., IL6 and TNF- $\alpha$ ), as a treatment for COVID19 (Guo et al. 2020; Touret and de Lamballerie 2020). Overall, the high infectivity of COVID-19 stemming in part by inflammation caused by cytokine storms urgently calls for additional novel studies as well as treatment options to curb its global spread.

\section{Neuroinflammation and CNS pathology}

Electron microscopy (EM) images as well as reverse transcription polymerase chain reaction (RT-PCR) performed during the autopsy of SARS patients revealed a significant number of viral particles and SARS-CoV-1 genome sequences in the cytoplasm of neurons (Gu et al. 2005). This finding is suggestive of the ability of SARS-CoV-1, and by extension SARS-CoV-2, to access anatomically privileged organs such as the brain. Along these lines, certain neurological symptoms (i.e., dizziness, ataxia, seizure, nerve pain, and impairments relating to vision, taste, and smell) have been reported to affect up to $30 \%$ of patients infected with SARS-CoV-2 (Li et al. 2020; Mao et al. 2020).

SARS-CoV-1 has been found in the brains of humans and animal models where the brainstem was heavily infected (Li et al. 2020). Similarly, SARS-CoV-2 RNA has now been documented within different areas of the brain including the cerebellum and medulla oblongata (Meinhardt et al. 2020). The murine coronavirus known as mouse hepatitis virus (MHV) provides a model system for the in vivo study of viral tropism and pathogenesis in the CNS, including encephalitis and multiple sclerosis (Weiss and Leibowitz 2011). Following MHV infection, neutrophils, macrophages, and natural killer (NK) cells are the first to be recruited to the CNS (Bergmann et al. 2006). In the CNS, MHV infection also results in the induction of chemokines (e.g., CXCL9, CXCL10, CCL2, CCL3, and CCL5), cytokines (e.g., IL1 $\alpha$, IL1 $\beta$, IL6, and IL12), and matrix metalloproteinases (MMPs) (Bergmann et al. 2006). As previously mentioned, some of these proinflammatory cytokines, including IL1 $\beta$, IL6, and IL12, have been detected in plasma samples of both SARS-CoV-1 and SARS-CoV-2 patients (Guo et al. 2020; Huang et al. 2020). Furthermore, microglia, the resident immune cells of the brain, are known to elicit the release of IL1 $\beta$, IL6, and TNF- $\alpha$ in response to infection in the CNS (Wang et al. 2015). Collectively, these cytokines contribute to neurodegeneration elicited by sustained inflammation. Chemokine and cytokine expression may additionally impact the permeability of the blood-brain barrier (BBB), thereby modifying the CNS-infiltrating cell populations (Bergmann et al. 2006). Production of MMP-9 (a metalloproteinase with effects on BBB permeability) by neutrophils and upregulation of adhesion molecules on CNS endothelium leads to relaxation of the BBB, facilitating the ensuing entry of additional inflammatory cells into the CNS to combat the infection (Bergmann et al. 2006). Collectively, these data imply that a secondary cytokine storm may initiate in the CNS, resulting in the neurologic symptoms that have been associated with COVID-19. 
Regulatory mechanisms aimed at curbing host immune responses with the intention of maintaining CNS integrity can inadvertently lead to the lack of viral clearance. Growing evidence suggests that coronaviruses can infect the CNS possibly by first entering peripheral nerve terminals, allowing access to the CNS via a synapse-connected route $(\mathrm{Li}$ et al. 2020). This pathway was studied in the primary motor cortex of a rat model infected with swine hemagglutinating encephalomyelitis virus (HEV), a type of $\mathrm{CoV}$ ( $\mathrm{Li}$ et al. 2013). Here, it was discovered that the virus spread from neuron to neuron via membranous-coated-mediated endocytosis using synaptic junctions, as evidenced by the presence of viral particles in axons, invaginations of presynaptic membranes, synaptic clefts, and postsynaptic cytoplasm $(\mathrm{Li}$ et al. 2013). This begs the critical question as to whether CNS infection by SARS-CoV-1 or SARS-CoV-2 can lead to neuronal injury. In support of this, multiple independent studies revealed the presence of SARS-CoV-1 proteins, including the viral antigen protein " $\mathrm{N}$ " in the brain of infected individuals (Ding et al. 2004; Gu et al. 2005; Xu et al. 2005). Another animal study using transgenic mice expressing human ACE2 receptor that were intranasally and intracranially infected with SARS-CoV-1 saw an extensive neuronal infection in the brain (measured by plaque assays and immunohistochemical staining for the viral $\mathrm{N}$ protein) followed by death despite minimal infection in the lungs (Netland et al. 2008). Taken together, these data suggest that neurons are susceptible to SARS-CoV-1 infection. Considering the similarities in viral structure and infection pathway of SARS-CoV-1 and SARS-CoV-2, the above data could be applicable to COVID-19. As such, neurologic symptoms observed in COVID-19 patients could generate from the invasion of the CNS by SARS-CoV-2, potentially via infection of the neurons and/or neuroinflammation, as ACE2 and other potential receptors such as neuropilin-1 expression have also been detected in the CNS (Barrantes 2020; Davies et al. 2020; Harmer et al. 2002). Likewise, proinflammatory cytokines (e.g., IL1 $\beta$, IL6, and TNF- $\alpha$ ) primarily linked to SARS-CoV-1 immunopathology have been shown to be upregulated in the brains of transgenic mice expressing ACE2 (McCray et al. 2007).

Neurological symptoms from COVID-19 have been detected weeks past the acute phase (Groiss et al. 2020). Through the use of electrophysiological studies (e.g., electroencephalography), Groiss et al. found that both the peripheral nervous system and the central nervous system were affected by SARS-CoV-2 in 4 male patients. Delirium was seen in these patients and cognition was impaired even after delirium passed (Groiss et al. 2020). Another study showed 4 children with COVID-19 who displayed similar neurological symptoms (e.g., encephalopathy, headache, brainstems with signs of dysarthria/dysphagia, meningism, cerebellar ataxia, muscle weakness, reduced reflexes, and lesions in the splenium of corpus callosum) had little to no respiratory symptoms (Abdel-Mannan et al. 2020). Therefore, Abdel-Mannan et al. suggested to test children for SARS-CoV-2 if neurological symptoms are displayed even with no other typical COVID-19 symptoms (AbdelMannan et al. 2020).

Recently, a study conducted by Mao et al. on a cohort of 214 COVID-19 hospitalized patients revealed neurological symptoms in $36.4 \%$ of patients and this percentage increased to $45.5 \%$ in more severe cases (Mao et al. 2020). Neurological manifestations included acute cerebrovascular events, dizziness, seizure, headache, impaired consciousness, nerve pain, loss of smell, loss of vision, loss of taste, muscle injury, and stroke such as cerebral venous thrombosis (blood clot in the venous sinuses of the brain) which may lead to death (Mao et al. 2020, Tu et al. 2020). Researchers also found that patients with CNS symptoms had lower lymphocyte levels, platelet counts, and higher blood urea nitrogen (Mao et al. 2020). As such, the immune system of these patients was suppressed, paving the way for a more severe infection. Therefore, the CNS manifestations associated with COVID-19 could potentially be explained by the presence of the ACE2 receptor in the CNS by providing a pathway for SARS-CoV-2 to bind to and infect cells (Hamming et al. 2004). Another theory postulates that SARS-CoV-2 enters and invades the CNS via the nasal route hence the loss of smell symptom experienced by some patients (Mao et al. 2020). This is supported by a study by Meinhardt et al. which found SARS-CoV-2 through anatomically distinct areas of the brain and nose (e.g., olfactory mucosa, olfactory bulb, olfactory tubercle, oral mucosa, trigeminal ganglion, medulla oblongata, and cerebellum), with the highest amounts being associated with the olfactory mucosa beneath the cribriform plate.

\section{Loss of olfactory and taste functions}

As mentioned earlier, an additional symptom experienced by SARS-CoV-2-infected patients has been the sudden and complete loss of olfactory function. Reports of multiple patients from around the globe have been documented (Gautier and Ravussin 2020; Gilani et al. 2020; Moein et al. 2020; Yan et al. 2020). More specifically, a woman in her 40 s diagnosed with SARS-CoV-2 (i.e., positive RT-PCR test), also presented with loss of smell, without dysgeusia and nasal obstruction, but with inflammation in the olfactory cleft confirmed by magnetic resonance imaging (MRI) (Eliezer et al. 2020). The olfactory cleft allows the flow of odors to the olfactory epithelium and subsequently to the olfactory bulb. This one patient was unable to detect odors such as phenyl-ethyl-alcohol (flower rose), cyclotene (caramel), isovaleric acid (goat cheese), and undecalactone (fruits), and skatole (manure) (Eliezer et al. 2020). The 
olfactory epithelium (also known as the olfactory mucosa) is composed of epithelial cells, basal cells, and olfactory receptor neurons (Chen et al. 2017). These cells respond to cytokines, such as TNF- $\alpha$ and IL1 $\beta$ (Chen et al. 2017). Interestingly, SARS-CoV-2 infection has been shown to cause an increase in expression of these same cytokines (Guo et al. 2020; Huang et al. 2020). Thus, the pathophysiology of SARS-CoV-2 may cause simultaneous effects on the lower respiratory tract, while also affecting neighboring cells (as present in the respiratory tract), resulting in effects on the CNS, such as in this case.

Loss of taste, like loss of smell, has been observed in COVID-19-infected individuals. Changes in saliva rate, flow, and content (e.g., hormones, enzymes, ions) are proposed to have a role in the loss of taste (Abduljabbar et al. 2020). Furthermore, the loss of smell/taste has been described as "the most discriminative symptom between seropositive and seronegative persons" in a population-based study within the Netherlands (Vos et al. 2020). This study took serological samples and used multiplex-immunoassays to look for the presence of IgG antibodies against SARS-CoV-2 spike protein in the population (3207 participants) along with a questionnaire and found that $53 \%$ of individuals with SARSCoV-2 antibodies experienced loss of taste/smell (Vos et al. 2020). Similar findings have been reported in other studies, and there is reason to believe that self-reported loss of smell/ taste is lower than reported (Gözen et al. 2020). Gözen et al. showed that out of the 59 patients tested, $83 \%$ were found to have loss of smell when Sniffin' Sticks tests were used but only $52.5 \%$ of patients self-reported loss of smell as a symptom. Another study showed that loss of smell and loss of taste were some of the most persistent symptoms 125 days of symptom onset indicating again the potential neurological impacts of COVID-19 (Petersen et al. 2020). These studies are representative of the growing interest in the effects of COVID-19 within the CNS and PNS and demonstrate the long-lasting effects even after viral clearance.

\section{Chronic COVID syndrome}

There is now a growing number of individuals who have chronic COVID syndrome (CCS; aka long-haulers) who have mostly recovered from the acute COVID-19 phase but have lingering or new symptoms months after infection (Baig 2020). As this is a developing pandemic, there is still much to learn but there already are studies that have analyzed large data sets of CCS cases which have helped to characterize the symptoms and groups most afflicted (Baig 2020; Graham et al. 2021; Huang et al. 2021; Lopez-Leon et al. 2021).

Like acute COVID-19, CCS impacts a variety of organs and displays a range of symptoms. Some of the most prevalent symptoms include sore throat, chills, tachycardia, extreme fatigue, hair loss, inability to perform daily tasks, shortness of breath, muscle pain, chest pain, insomnia, gastrointestinal problems, and neurological symptoms (Baig 2021; Graham et al. 2021; Lopez-Leon et al. 2021). The typical neurological symptoms are as follows: brain fog, headache, attention disorder, numbness/tingling, loss of smell and/or taste, dizziness, and blurred vision (Baig 2021; Graham et al. 2021; Huang et al. 2021; Lopez-Leon et al. 2021). In one study, Graham et al. performed 100 neurological exams and determined through tests of recall and serial sevens that these CCS individuals had short-term memory deficit as well as an attention deficit (Graham et al. 2021).

There have now been a few studies that have characterized the people who are more at risk. In a study of 1407 COVID19 cases from the University of California COVID Data Set, $27 \%$ had symptoms upwards of 60 days and of these CCS cases, $32 \%$ were asymptomatic during the acute phase (Huang et al. 2021). Huang et al. also found women to be more at risk of having CCS. This was supported in another study that found $70 \%$ the CCS in the study of 150 cases were women (Graham et al. 2021). In the aforementioned study by Graham et al., individuals with comorbidities such as such as depression, anxiety, and autoimmune disease were also at a higher risk of CCS (Graham et al. 2021). There is still much to be understood about CCS, but these first few studies have shown the importance of reducing the transmission of SARS-CoV-2, not just for acute COVID-19 but CCS as well.

\section{Development of diagnostics}

The primary goal for SARS-CoV-2 containment is to reduce transmission and, thus, reduce infection and prevent symptoms like those of the CNS. Currently, outside of vaccination, the only method available to reduce transmission is through identifying and isolating infectious persons (Cheng et al. 2020). To do this, efficient diagnosis is required, and as symptoms alone are not enough for diagnosis, diagnosis is contingent upon the availability of tests, resources, and the time to obtain diagnostic results (Cheng et al. 2020; Udugama et al. 2020).

Current diagnostic tests include nucleic acid testing, antibody testing, and protein testing. The accuracy of these tests is defined by their sensitivity and specificity, positive tests in patients with disease, and negative tests in healthy individuals, respectively (Weissleder et al. 2020). Many aspects of diagnostic tests impact their sensitivity and specificity, one of those being sample collection sites. The two most common specimens for SARS-CoV-2 are nasopharyngeal samples and blood serum (Esbin et al. 2020). Nasopharyngeal swab samples test for viral RNA and collect high viral titers starting on the first day of infection whereas blood serum samples test for host antibodies as SARS-CoV-2 levels are 
low in blood (Cheng et al. 2020; Esbin et al. 2020; Udugama et al. 2020).

\section{Nucleic acid testing}

Nucleic acid testing (NAT) is the primary method for diagnosing COVID-19 as it currently has the earliest detection and is the most sensitive (Esbin et al. 2020; Udugama et al. 2020). NAT results show the presence or absence of known genetic sequences (genetic markers) within the genome of the virus under investigation (Udugama et al. 2020). The CDC suggests targeting two regions of the viral nucleocapsid (N) gene, N1 and N2, as well as human RNase P gene to confirm RNA extraction (CDC 2020a). Nucleocapsid genes, viral envelope (env), RNA-dependent RNA polymerase (RdRp), and others may also be targeted (WHO 2020b). NAT for SARS-CoV-2 is mainly performed on nasopharyngeal swabs due to their high sensitivity and ability to detect viral titers the first day of infection (Cheng et al. 2020; Esbin et al. 2020).

Many nucleic acid tests rely on RT-PCR. To date, there are over 181 commercialized RT-PCR kits approved for emergency use by the FDA (FDA 2021d; Foundation for Innovative New Diagnostics [FIND] 2021). Briefly, there are three basic steps to the CDC RT-PCR kit: sample collection/ transportation, lysis and RNA purification, and amplification (FDA 2021c). Esbin et al. have an informative summary comparing some of the new commercialized kits (Esbin et al. 2020). RT-qPCR has also been used in studies such as the one mentioned above, to map the presence of SARS-CoV-2 RNA throughout the brain (Meinhardt et al. 2020).

Other NATs are under development and a few are currently in use. These include CRISPR, isothermal amplification, and next-generation sequencing (NGS) (Broughton et al. 2020; Guo et al. 2020; Nat Biotechnol 2020; Weissleder et al. 2020; Yoshikawa et al. 2020). CRISPRCas12- and CRISPR-Cas13-based assays simultaneously perform reverse transcription and isothermal amplification from RNA extracted from nasopharyngeal or oropharyngeal swabs; then, it goes through Cas 12 or Cas 13 detection of coronavirus sequences with no cross reactivity from related coronavirus strains (Broughton et al. 2020). There are currently 2 CRISPR diagnostic tests approved for commercial use by FDA EUA (FDA 2021d; FIND 2021). Isothermal amplification including a new battery powered kit is used for rapid testing in remote locations (Yoshikawa et al. 2020). There are currently 8 isothermal amplification tests approved by FDA EUA (FDA 2021d; FIND 2021). NGS is used for high-volume screening and population management, and there are now 4 approved commercially used FDA EUA (FDA 2021d; FIND 2021; Nat Biotechnol 2020).

\section{Serological testing}

Serological testing detects antibodies (e.g., immunoglobulins) or interleukins (e.g., IL6) in a patient's blood serum (Esbin et al. 2020; Weissleder et al. 2020). Serological tests are rapid, robust, and easy (as easy as a finger prick); however, this testing method lacks specificity and relies on the host's production of antibodies which can take 5-10 days after the onset of symptoms (Cheng et al. 2020; Esbin et al. 2020; Lee et al. 2020). Although the FDA does not approve the sole use of serological testing for COVID19 diagnosis, there are over 75 serological tests FDA EUA for commercial use (including one at home test) that aid in the detection of post-infection syndrome and late presenting symptoms (CDC 2020a; FDA 2021b; FDA 2021c; FIND 2021). For example, in a case where an individual presented manic-like symptoms after recovery of vital signs, a serological test was used to find that the cerebrospinal fluid was positive for SARS-CoV-2-specific IgG (Lu et al. 2020a, b). Serological tests are also helpful for epidemiological and surveillance studies tracking antibody longevity and transmission dynamics and are also used as a tool to confirm negative results (CDC 2020a; Esbin et al. 2020; Weissleder et al. 2020). For these reasons, there are many companies working to create point-of-care serological tests (Lisboa Bastos et al. 2020).

Immunoassays are the main method used for antibody testing. Most infections incite the production of IgM first and then IgG, but in SARS-CoV-2 infections they are both produced around the same time (Lee et al. 2020). Le et al. suggest that both $\operatorname{IgG}$ and $\operatorname{IgM}$ levels may correlate to disease severity and have reported that IgG3 may be the dominant subtype in SARS-CoV-2 infection (Lee et al. 2020). While there are different types of immunoassays, the most common are CLIA (chemiluminescence immunoassay) and ELISA (enzyme-linked immunosorbent assay) due to their simple readouts (Lee et al. 2020). In addition to the wait time for antibody production, another main issue is cross-reactivity with past infections from other coronaviruses (e.g., SARS-CoV-1, MERS-CoV), or even current infections with endemic coronaviruses like MERS-CoV (Lee et al. 2020; Weissleder et al. 2020).

\section{Protein testing}

Viral antigen tests (VATs) currently probe for nucleocapsid (N) or spike (S) proteins on SARS-CoV-2 through nasopharyngeal or other respiratory tract samples (Weissleder et al. 2020). VATs are most accurate in the early phase of infection as intermediate phase and late phase have varied to consistently negative results, and current tests have too low sensitivity to rule out infection (Cheng et al. 2020; Hirotsu et al. 2020a). However, VATs are useful in tracking 
viral clearance in infected persons as there is a gradual loss of viral antigens over time as opposed to the positive/negative results seen with RT-qPCR, although the persistence of antigens does not mean infectious host (Hirotsu et al. 2020a).

There are a variety of tests for detecting viral antigens. The most common are through the use of lateral flow assays or single antigen ELISA tests and take around an hour to complete (Steiner et al. 2020; Weissleder et al. 2020). LUMIPULSE is a chemiluminescence enzyme immunoassay that is high throughput with the ability to run $60-120$ samples in $30 \mathrm{~min}$ on automated machines and has the potential for hospitals to track viral clearance in patients (Hirotsu et al. 2020b). There are also monoclonal antibody tests in development that use monoclonal antibodies to test against the $\mathrm{N}$ proteins of SARS-CoV-2 and may create a rapid antigen test (Cheng et al. 2020). Other antigen tests include western blots, virus neutralization test (VNT) that uses antibodies against specific virus proteins to identify the virus, and immunofluorescence microscopy (IFM) which uses antibody interaction with virus proteins to create fluorescent glow that can be visualized with microscopy to identify the virus (Cheng et al. 2020; Weissleder et al. 2020). Protein testing can also be used for understanding the SARS-CoV-2 infection. For example, Song et al. used immunolabeling against the $\mathrm{N}$ protein in their transgenic mice (expressing human ACE2) to show the viral infection of SARS-CoV-2. This experiment showed the presence of SARS-CoV-2 throughout the brain of the infected mice, specifically in the neural cells of the fore brain, as well as the $S$ protein in human brains (Song et al. 2021).

\section{Point-of-care testing}

The need for rapid point-of-care testing (on-site diagnosis) is crucial for infected individuals to isolate themselves. Many tests have been developed for point-of-care (POC) diagnosis of COVID-19, but POC tests tend to have lower throughput, are more expensive, or are not automated (Weissleder et al. 2020). Although there are issues with POC testing, quick diagnosis in hospitals allows for improved infection control measures including the following: patient flow, enrollment of patients into clinical trials, admission to secondary care, reduction of nosocomial infection in non-COVID-19 positive patients who might otherwise be exposed, and reduction in bed movement which reduces exposure to cleaning staff and healthcare staff (Brendish et al. 2020). This can be especially useful with individuals who display CNS symptoms without the tell-tale respiratory symptoms that may otherwise fly under the radar (Abdel-Mannan et al. 2020; Mao et al. 2020).

There are now a variety of POC tests. LAMPs are popular POC tests as there is no need for thermocyclers and results can be ready in $20 \mathrm{~min}$ (Orooji et al. 2021). There have been advances in PCR kits which can produce results in less than 30 min via cartridges or lateral flow technology, and 15-min immunoassays (Cheng et al. 2020; Orooji et al. 2021; Weissleder et al. 2020). Other POC tests that are in development now include microarrays which are cost effective, non-fluorescent, low-density oligonucleotide assay tools that have been used for whole genomic detection of past coronaviruses, and mobile analysis platforms (MAPS) which have been used to diagnose past acute respiratory illnesses (de Souza Luna et al. 2007; Hardick et al. 2018; Prabhakar \& Lakhanpal 2020).

\section{Ancillary tests and programs}

On top of these diagnostic tests, there are a variety of tools that epidemiologists, healthcare workers, businesses, and individuals may use that help to determine possible exposure, detect early symptoms, and confirm COVID-19 infections. Health care professionals may use other tests to help determine if a patient is COVID-19 positive along with the abovementioned tests including $\mathrm{CT}$ scans and ultrasounds (Cheng et al. 2020; Taylor et al. 2020). Healthcare professionals may also use a variety of non-contact tools to determine abnormal breathing and/or heart rate with less exposure to themselves. For example, RBG-thermal cameras can be used to diagnose COVID-19 on a mask wearing individual with $83.7 \%$ accuracy (Taylor et al. 2020).

Temperature monitoring has become a useful tool used to detect infected individuals with low-grade fevers and little to no symptoms. This period typically occurs in the early stage of COVID-19 where viral shed is highest and so detecting a low-grade fever can encourage testing and isolation (Zhou et al. 2020a, b, c). Infrared thermography especially has become useful as it can detect body temperature without physical touch and can screen for potential infected people in high-risk areas like airports. All these diagnostic methods help to identify infected individuals which leads to isolation and a reduction of viral transmission, helping to prevent infection and thus CNS symptoms.

\section{Therapeutics for the treatment of COVID-19}

Due to the novelty of SARS-CoV-2 and the spread of the virus, scientists and clinicians have worked together to discover therapeutics for the treatment of COVID-19 and alleviants for the disease symptoms. As described above, there are a variety of systems impacted including the respiratory tract, gastrointestinal tract, central nervous system, and systemic inflammation. Due to the heterogeneity in symptoms and disease severity, as well as the heterogeneity across populations, a variety of treatments are needed. The rapid spread of the virus has resulted in many drugs and therapeutics 
that are already approved for other similar infections like SARS and MERS or for general antiviral activities to be used for potential COVID-19 treatment (Reddy et al. 2020). For example, the S proteins of SARS-CoV-2 and SARS$\mathrm{CoV}-1$ share $77.5 \%$ identical amino acid sequence and use the ACE2 receptor to enter host cells ( $\mathrm{Li}$ et al. 2003; Walls et al. 2020; Wrapp et al. 2020; Zhou et al. 2020a, b, c). As such, the interaction of the $\mathrm{S}$ protein of SARS-CoV-2 with the host cellular receptor(s) (e.g., ACE2) is the main target for inhibiting viral entry into cells ( $\mathrm{Li}$ et al. 2005). Additionally, other therapies like stem cell therapy are also being considered (Harrell et al. 2020; Kim et al. 2020).

\section{Host protein-targeted approaches}

One method of viral suppression is through targeting host proteins that play a role in viral replication. Human receptor ACE2 and TMPRSS2 are the main host proteins targeted by therapeutics with 115 and 32 clinical trials currently underway, respectively (Clinical Trials 2021). Vitamin D and calcitriol (which have known anti-inflammatory effects) are studied for their preemptive effects to help regulate angiotensin-renin mechanisms, which increase lipopolysaccharide permeability into lungs and reduce severe lung damage (Sarwar et al. 2020; Xu et al. 2017). Typical ACE2 inhibitors and receptor antagonists Captopril and enalapril, and iosartan and valsartan, respectively, are under study along with new inhibitory methods including single-chain variable fragments, VHH domains, nanobodies, fusion of human recombinant soluble ACE2 (hrsACE2) to an immune-adhesion molecule, and even the use of inhibitory peptides isolated from marine organisms (Festa et al. 2020; Zhou et al. 2020a, b, c).

The primary focus of TMPRSS2 inhibition is on camostat mesylate. Camostat mesylate is a serine protease inhibitor that has been shown to reduce inflammatory markers IL6, TNF- $\alpha$, and TGF- $\beta$ as well as inhibit TMPRSS 2 and thus block viral entry and replication (Breining et al. 2021). Other drugs under study for TMPRSS2 inhibition are aprotinin and nafamostat mesylate (Bojkova et al. 2020; Zhou et al. 2020a, b, c). Nafamostat mesylate has shown neuroprotective effects with neurovascular ischemia and has been shown to reduce the production of inflammatory cytokines, which could be another benefit when used by COVID-19 individuals afflicted with CNS cytokine storm brain injury (Duan et al. 2018; Ghali and Ghali 2020; Li et al. 2016).

While the main host proteins involved with SARS-CoV-2 entry (ACE2 and TMPRSS2) are important targets for therapeutics, there are also other proteins that may play a role in SARS-CoV-2 replication including GRP78 and CD147. As discussed above, GRP78 may be a secondary receptor, and a study showed an increase in the inhibitory effect of viral entry through the use of four polyphenols which bind to GRP78 (Allam et al. 2020). CD147, another potential secondary receptor, has been shown to be blocked by meplazumab, a humanized anti-CD147 antibody that is used to treat malaria (Wang et al. 2020a, b, c).

\section{Monoclonal antibodies}

In recent years, monoclonal antibodies have emerged as powerful therapeutic tools for a variety of pathologies, including those related to cancer, immunology, and cardiovascular and respiratory diseases (Singh et al. 2018). In general, this form of immunotherapy relies on the manufacturing of monoclonal antibodies that are able to bind specifically to certain antigens. This binding consequently results in the induction of an immune response that will eliminate the targeted cell(s) (Zhou et al. 2020a, b, c).

Antibody-based treatments are a useful option for immediate effects or disease prevention for people at high risk of infection, as well as in the treatment of infected patients to prevent disease progression (Nie et al. 2004). To date, there is FDA EUA of bamlanivimab, and the combinations of bamlanivimab/etesevimab, and casirivimab/imdevimab for the treatment of COVID-19 (FDA 2020b, FDA 2021a). Similar to these EUA treatments, most monoclonal antibodies under consideration work by targeting the SARS-CoV-2 S protein (e.g., 80R, CR3013, CR3014, CR3022, and m396) (Chung et al. 2020; National Center for Biotechnology Information [NCBI] 2020; Sui et al 2004; ter Meulen et al. 2006; van den Brink et al. 2005). Recently, Wang et al. reported the first human monoclonal antibody (47D11) against the spike receptor of SARS-CoV-2, as well as SARS-CoV-1, which could potentially be used to control COVID-19 spread (Wang et al. 2020a, b, c). Several other monoclonal antibodies have been identified as potential candidates to neutralize SARS-CoV-1 and have been reviewed elsewhere (Jin et al. 2017; Liu et al. 2020a, b, c, d; Nie et al. 2004; Prabakaran et al. 2009; Zhou and Zhao 2020).

Antiviral monoclonal antibodies have also been developed to neutralize proteins associated with SARS pathogenesis such as antibodies against IL6/IL6R, TLR3, CD16, immunoreceptor tyrosine-based activation motif (ITAM), dendritic cell-specific intercellular adhesion moleculegrabbing nonintegrin (DC-SIGN), intercellular adhesion molecule 3 (ICAM-3), or interferon $\gamma$-inducible protein 10 (IP10/CXCL10) (Liu et al. 2020a, b, c, d). Antibodydependent opsonization or complement activation is the primary mechanism of virus clearance after neutralization (Coughlin and Prabhakar 2012).

Currently, monoclonal antibody treatment of COVID-19 has focused on respiratory tract, but due to their antiinflammatory effects, monoclonal antibodies should be studied to help mediate CNS distress. Previous studies have found monoclonal antibodies to be effective in the treatment of a 
variety of CNS and PNS diseases in animal models such as stroke, brain injury, and epilepsy (Liu et al. 2007; Nishibori et al. 2019; Wang et al. 2017; Zhang et al. 2011). Due to the similarity of CNS damage from SARS-CoV-2 infection, it would be beneficial to further investigate these effects.

\section{Suppression of immune response}

The release of cytokines results in the induction of an immune response that aids in viral clearance. As described above, with respect to SARS-CoV-2, the most severe infections are often associated with the development of cytokine storms that may lead to lung damage, incite CNS inflammation, and may ultimately lead to death (Chen et al. 2020a, b). Elevated levels of pro-inflammatory cytokines (e.g., TNF $\alpha$, IL1 $\beta$, IL2, IL6, IFN $\alpha$, IFN $\beta$, IFN $\gamma$, and MCP1) are observed in many patients with severe infections. Therefore, the use of existing approved treatments coupled with the development of anti-inflammatory therapies may help reduce the mortality rate of SARS-CoV-2. Intravenous immunoglobulin (IVIG), tocilizumab, and methylprednisolone have been used to manage cytokine storms and to halt respiratory failure in severe SARS-CoV-1 patients, and could potentially be utilized as treatments for the current COVID-19 outbreak (Chen et al. 2020a, b; Lee 2014). Currently, there are 7 completed clinical trials that investigated IVIG therapy against COVID-19 that measured the ability of IVIG to reduce the immune response through providing an anti-inflammatory, immunomodulatory effect in severe cases but none is approved by FDA EUA at this time (Clinical Trials 2021).

Tocilizumab is marketed as a rheumatoid arthritis drug and can bind to the membrane bound and soluble forms of IL6 receptor (Kaly and Rosner 2012; Zhang et al. 2020a, b, c, d). In a recent study, patients with SARS-CoV-2induced ARDS displayed clinical improvements after taking tocilizumab for 5 days (Xu et al. 2020a, b). Additionally, siltuximab, emapalumab, and anakinra are being tested in clinical trials to demonstrate the efficacy of these drugs in alleviating severe symptoms in SARS-CoV-2 patients (Clinical Trials 2021).

Despite the efficient use of corticosteroids (e.g., methylprednisolone) in the reduction of early acute phase viral infection, their use is not routinely recommended to treat SARS-CoV-2 patients (Russell et al. 2020a; Russell et al. 2020b; Russell et al. 2020a, b, c). Corticosteroids may not be effective and may even produce adverse effects as seen in prior cases (e.g., avascular osteonecrosis in SARS, a decreased ability to eradicate virus in later stages of MERS; and increased mortality rate and secondary infections in influenza patients) (Arabi et al. 2018; Russell et al. 2020a; Russell et al. 2020b; Russell et al. 2020b; Chang 2005; Griffith et al. 2005; Lee et al. 2015; Rodrigo et al. 2016).

Cytokine signaling pathways are largely dependent on the JAK-STAT pathway. Therefore, Janus kinase (JAK1/JAK2) inhibitors (e.g., baricitinib or tofacitinib) could be used to block cytokine release in order to dampen inflammation. Baricitinib is used as an anti-rheumatic drug and may reduce SARS-CoV-2 entry to the host cells via interference with the viral endocytosis moderators: adaptor protein-2 complex (AP2) and adaptor-associated kinase-1 (AAK1) (Richardson et al. 2020a). Baricitinib has also been used in the CNS of an animal model, and resolved hallucinations in a COVID19 patient, potentially indicating its ability to reduce neurological deficits (Hoang et al. 2021; Richardson et al. 2020b). Since then, baricitinib along with antiviral remdesivir has received FDA EUA for patients over 2 years of age who require supplemental oxygen, invasive mechanical ventilation, or extracorporeal membrane oxygenation (FDA 2020a).

\section{Convalescent plasma therapy}

Convalescent plasma (CP) from recovered SARS-CoV2-infected patients could be potentially beneficial to treat SARS-CoV-2-infected patients (Hoffmann et al. 2020). In this sense, $\mathrm{CP}$ containing antibodies developed against the previous infection (i.e., against viral proteins) could be used to neutralize viral infection and lead to viral clearance (Marano et al. 2016). CP has been used as a therapeutic option in a variety of viral infections, such as Ebola virus, SARS-CoV-1, avian influenza A(H5N1) virus, and influenza A(H1N1) virus (Chen et al. 2020; Hung et al. 2013; Luke et al. 2006). SARS patients who received CP from SARSrecovered donors observed a shorter length of hospital stay and a lower mortality rate relative to the untreated group (Soo et al. 2004; Cheng et al. 2005).

Many patients recovering from SARS-CoV-2 infection have high titers of neutralizing antibodies $(<1: 640)$ against several SARS-CoV-2 proteins within 2-3 weeks following the onset of the symptoms (Shen et al. 2020). These neutralizing antibodies can be detected by ELISA and other quantitative tests (Shen et al. 2020). Therefore, plasma transfusion could be given to high-risk cases in order to reduce the severity of the disease in combination with antiviral therapies.

A recent study reported improvement of clinical symptoms in 6 patients after $\mathrm{CP}$ treatment including a reduction in body temperature, viral loads, and C-reactive protein (Zhang et al. 2020). Additional studies are required for large testing groups with a proper control group, to evaluate whether the observed improvement is caused by the $\mathrm{CP}$ or antiviral drugs. Moreover, it is crucial to determine whether $\mathrm{CP}$ should only be used for the critical patient, as well as the 
efficient time that is needed to administer plasma transfusion (Shen et al. 2020).

It is also worth noting that patients that receive $\mathrm{CP}$ transfusions may develop severe allergies, transfusion-associated circulatory overload (TACO), and transfusion-related acute lung injury (TRALI) (Chun et al. 2016). For instance, a MERS patient who received CP from a cured MERS-CoV donor displayed TRALI after transfusion (Chun et al. 2016). Adverse reactions can occur due to failure of the antibodies being neutralized in the host. Ultimately, this may result in entry of SARS-CoV-2 into the host cells and increase inflammation which can lead to severe pulmonary and/or CNS disease (de Alwis et al. 2020). Therefore, the use of CP should be cautiously approached. Currently, the FDA has not approved $\mathrm{CP}$ as a treatment method but does provide guidelines on CP use as an investigational product (FDA 2021e).

\section{Stem cell-based therapy}

Stem cell therapy has received attention as an alternative supportive treatment for patients infected with COVID-19. Early reports emerging from China have provided evidence that transplantation of allogenic mesenchymal stem cells (MSCs) is associated with improved clinical outcomes of patients with varying stages of COVID-19-associated pneumonia (Liang et al. 2020; Leng et al. 2020). The use of MSCs as a therapeutic strategy for critical cases of COVID19 has been the focus of a recent review which emphasizes their reparative functions (Atluri et al. 2020).

MSCs represent one of the most widely studied types of stem cells, and in recent decades, it has been well established that MSCs possess broad regenerative and restorative properties. These properties are believed to be modulated through the secretion of paracrine factors (i.e., growth factors, cytokines, extracellular vesicles) which regulate immunomodulatory and inflammatory processes in damaged or diseased tissues (Baraniak and McDevitt 2010; Phinney and Pittenger 2017; Samsonraj et al. 2017; Wang et al. 2016). Specifically, MSCs have demonstrated the ability to regulate proliferation, activation, and function of key immune cells (e.g., macrophages, B cells, effector/ regulatory T-cells). Additionally, MSCs have been shown to exert anti-inflammatory effects through the secretion of various immunosuppressive molecules such as TGF- $\beta$, PGE2, IDO, and NO, as well as through the polarization of macrophages from an M1 to M2 phenotype which reduces the expression of pro-inflammatory cytokines (Gao et al. 2016; Harrell et al. 2019; Volarevic et al. 2017; Weiss and Dahlke 2019). Accordingly, numerous clinical trials have evaluated the therapeutic potential of MSCs in various diseases such as cardiac, bone, neurodegenerative, autoimmune, kidney, and lung (Marquez-Curtis et al. 2015; Trounson and McDonald 2015). Due to these holistic effects, MSCs hold great promise for the future of tissue engineering and regenerative medicine.

With respect to COVID-19 infection, an overactivation of the immune system can induce a cytokine storm in severe and critical severe cases (Zhang et al. 2020). As discussed above, in the absence of therapeutic intervention, this cytokine storm can lead to significant pulmonary inflammation and extensive lung damage, ARDS, secondary infection, enhanced neurological symptoms, and sepsis that may ultimately result in death (Atluri et al. 2020). Therefore, preventing and/or reversing the cytokine storm may be paramount to treating critically ill COVID-19 patients (Atluri et al. 2020; Leng et al. 2020). Thus, due to their potent immunomodulatory and anti-inflammatory properties, MSCs may be well-suited for therapeutic intervention in these cases.

Throughout the last decade, MSCs have been utilized in a number of pre-clinical and clinical experiments relating to CNS and lung pathologies ranging from ARDS and pneumonia to Parkinson's disease and multiple sclerosis. Accordingly, there is accumulating evidence to support their potential therapeutic use in these conditions (Harrell et al. 2019; Wilson et al. 2018). For example, several in vivo studies have shown that MSCs can reduce lung injury and promote repair in animal models of ARDS and pneumonia. Here, some of the key efficacy outcomes were related to the modulation of inflammatory cytokine expression and neutrophil influx, regeneration of alveolar type II cells, regeneration of the alveolar-epithelial barrier, and reduction of cellular apoptosis (Asmussen et al. 2014; Curley et al. 2017; Gupta et al. 2007; Harrell et al. 2019; Lee et al. 2009; Kotani et al. 2017; Zhu et al. 2017). In the CNS, MSCs have shown tissue repair, modulation of inflamed tissue, and improved neurological functions in clinical and disease models (Branscome et al. 2020; Harris et al. 2012; Simorgh et al. 2019; Wilson et al. 2018). Specifically, in a mouse model of Parkinson's disease, MSCs were shown to improve behavior, increase dopamine transporters, among other benefits (Simorgh et al. 2019). Since ARDS, pneumonia, and neuronal damage can arise from COVID-19 infection, it stands to reason that COVID-19 patients may benefit from MSC therapy.

As mentioned above, two recent reports from China have already evaluated the therapeutic potential of clinical grade allogeneic MSCs against COVID-19-associated pneumonia. These studies showed improvements in vital signs, reduction of pneumonia, decrease in TNF, and an increase in IL10, VEGF, and IP10, as well as cellular indications of the reversal of the cytokine storm (Leng et al. 2020; Liang et al. 2020). Importantly, Leng et al. showed that transplanted MSCs were ACE2 and TMPRSS2 negative via RNA-seq analysis, confirming their natural immunity against SARS-CoV-2 (Leng et al. 2020). Collectively, these results suggest that MSCs have the potential to 
reverse immune system over-activation to promote endogenous tissue repair. While these studies are promising, further research is warranted to validate these findings.

It is also crucial for future studies to better define the mechanisms of action through which MSCs act in damaged tissue. In recent years there has been a surge of interest in extracellular vesicles (EVs), especially exosomes, and it is now widely recognized that these vesicles are responsible for mediating many of the reparative and regenerative effects of MSCs and this topic has been extensively reviewed elsewhere (Joo et al. 2020; Marote et al. 2016; Mendt et al. 2019). Briefly, EVs are nanosized vesicles released by virtually all cell types and, furthermore, are enriched with a rich assortment of bioactive cargo including RNAs (both small and long noncoding), cytokines, and proteins. These molecules can be horizontally transferred to recipient cells and, thus, have the ability to significantly affect cellular activity (Deng et al. 2018; Katsuda and Ochiya 2015). It is also worth noting that, from a therapeutic perspective, EVs offer certain advantages over stem cells due to their increased potency and stability, longer shelf life, and lower immunogenicity (Phinney and Pittenger 2017; Seo et al. 2019). In this sense, EVs represent a relatively novel paradigm for the field of regenerative medicine.

Similar to the previously discussed literature surrounding MSC-based therapy for lung and neurodegenerative pathologies, complementary studies involving the use of MSC EVs have revealed that these vesicles also possess the immunomodulatory, anti-inflammatory, antifibrotic, and antibacterial properties associated with their donor stem cells. A recent review nicely summarizes these experimental results in the context of asthma, ARDS, pneumonia, COPD, and idiopathic pulmonary fibrosis (IPF) (Cruz and Rocco 2017). In the context of the CNS, EVs provide additional benefits through their ability to cross the blood-brain barrier to deliver the therapeutic and regenerative qualities of MSCs (Branscome et al. 2020; Gorabi et al. 2019). It therefore stands to reason that an EV or exosome-based approach should also be considered for COVID-19 patients.

Due to the severity of the COVID-19 pandemic, it is imperative to investigate and exhaust all therapeutic options. Preliminary data strongly suggests that severely ill COVID19 patients may benefit from MSC transplantation and regulators have been called upon to minimize the regulatory burdens governing access to its use (Atluri et al. 2020). Meanwhile, next-generation strategies employing the use of MSC EVs should also be rigorously pursued. Overall, the therapeutic methods offered and under research are vast but there is little information on if treatments help mitigate the neurological symptoms seen with COVID-19, especially for CCS individuals. This highlights an important area to study as we move forward.

\section{Vaccines}

The goal of a vaccine is to stimulate the immune system to produce antibodies and gain immunity against SARS-CoV-2 infection without contracting COVID-19. Currently, the S protein is the main candidate for vaccine development as the $\mathrm{S}$ protein mediates entry into host cells. As such, antibodies against the $\mathrm{S}$ protein can block virus-host cell interactions, ultimately neutralizing the virus ( $\mathrm{Li}$ et al. 2005). The CDC explains that vaccine development follows the following prescribed steps: Exploratory stage, Pre-clinical stage, Clinical Development, Regulatory review and approval, Manufacturing, and Quality control (CDC 2020b). Due to the many stages that a new vaccine has to follow, WHO estimates that vaccine development can take as long as 10 years. However, the current COVID-19 crisis has substantially accelerated this process and it has taken less than a year to develop the current COVID-19 vaccines. To date, there are 3 COVID-19 vaccines with FDA EUA and several in clinical trials.

Two of the vaccines currently available in the USA are RNA vaccines. RNA vaccines are a relatively new type of vaccine that works through mRNA-encoded viral antigens, thus removing the genome integration step and providing an advantage over conventional vaccine approaches (Zhang et al. 2019). Furthermore, RNA vaccines can be developed faster and are more easily manufactured in large quantities than traditional vaccines (Amanat and Krammer 2020; Zhang et al. 2019). The two RNA vaccines with FDA EUA are mRNA-1273 (developed by the National Institute of Allergy and Infectious Diseases in collaboration with Moderna) and mRNA BNT 162b2 (developed by Pfizer) (Clinical Trials 2021). Both are double-dose vaccines that use an encoded mRNA SARS-CoV-2 S protein (Moderna 2020, Walsh et al. 2020). Once injected, the host immune cells produce and display the viral S protein which results in the activation of the host immune system and creation of antigens that target the $\mathrm{S}$ protein of the coronavirus and protect the host from future infection.

The third vaccine with FDA EUA is an adenoviral vector vaccine, which is one of the most common approaches in the development of vaccines, along with lentiviral vectors. These approaches have foreign genes which transduce the dividing cells, as well as the non-dividing cells. The lentiviral vectors target dendritic cells, as well as T-cells, to prompt an immune reaction (Pincha et al. 2010). The Janssen COVID-19 vaccine is a single-dose vaccine that encodes the SARS-CoV-2 $S$ protein in an adenovirus vector to stimulate an immune response similar to that of the mRNA vaccines discussed above (FDA 2021a; Johnson and Johnson 2021).

There are a few other types of vaccines that are also undergoing clinical trials including recombinant subunit vaccines, DNA vaccines, live attenuated vaccines, and inactivated virus vaccines summarized by Amanat and Krammer 
(2020). Lastly, there are some studies that have not yet been peer reviewed that show that vaccination has improved symptoms of brain fog and GI distress in cases of CCS, but as these are preliminary results, further research must be done (CDC 2021).

\section{Conclusion}

As discussed in this review, there have been great strides in SARS-CoV-2 research this last year. There are over 122,000 scientific papers in PubMed that discuss COVID-19, and publications increase daily along with our understanding of the disease. Here we try to summarize the major findings in SARS-CoV-2 biology, transmission, disease symptoms, diagnostic techniques, vaccines, and therapeutics.

SARS-CoV-2 is one of the seven known viruses within the Coronaviridae family that can infect humans. SARSCoV-2 is a single-stranded positive sense RNA virus similar to other coronaviruses like SARS-CoV-1 and MERS-CoV. The main route of transmission of SARS-CoV-2 is through the respiratory tract via droplets, but other routes of infection may include pet, fomite, aerosol, sexual, and bloodborne transmission. Entry of SARS-CoV-2 in to host cells is thought to be through the interaction between the viral spike protein and host receptors like ACE2, DPP4, CD147, and GRP78. Once in the host cell, SARS-CoV-2 replicates in the cytosol and infects the host. ACE2, proposed as (one of) the main receptor(s) for initial infection, is found in high concentrations in the lung alveolar epithelial cells and small intestine enterocytes which logically follows the respiratory and gastrointestinal symptoms seen in COVID-19 cases. Although mainly found in the above locations, ACE2 is also found throughout the body including nasal and CNS cells.

Once SARS-CoV-2 infects the body, the host can display a wide variety of symptoms that are associated with COVID-19. COVID-19 symptoms appear to worsen in older adults and individuals with comorbidities, but anybody can be infected. Symptoms usually occur within 5 to 6 days of infection (but may take up to 14 days) and impact many areas of the body. Typical symptoms include fever, cough, fatigue, sore throat, and shortness of breath. In more severe cases, pneumonia, lymphopenia, acute kidney injury, cardiac injury, lung damage, overactive immune system, ARDS, multi-organ failure, sepsis, and even death have been observed. CNS and PNS symptoms have also been observed including dizziness, ataxia, seizure, nerve pain, vision, taste, and smell impairments. The presence of SARS-CoV-2 has been shown to cause cytokine storms in the lower respiratory tract as well as a secondary cytokine storm within the brain which may result in additional lung damage as well as induce/increase neurological symptoms. In addition to acute COVID-19, there is now mounting evidence of chronic
COVID syndrome (CCS) which may impact individuals for months post exposure with symptoms such as fatigue, memory loss, attention deficit, brain fog, tachycardia, and shortness of breath.

The wide variety of symptoms associated with COVID19 make diagnosis through symptoms alone ill-advised, and thus, there are now many tests to determine if an individual has COVID-19. The most common are NATs via oropharyngeal samples as they are currently the most sensitive diagnostic tests and provide the earliest detection. The CDC has advised the use of the viral N1, N2, genes as well as human RNase P gene for accurate results. These RT-qPCR tests can be done in as little as $3 \mathrm{~h}$, but due to reagent and staffing shortages may take up to multiple days. Point-of-care test such as LAMPs, PCR kits, and immunoassays are also used as rapid tests, and can produce results in as little as 15-30 min. Other typical diagnostic methods have been unable to meet CDC standards for COVID-19 diagnosis but are used for other purposes. For example, serological tests and virus antigen tests are used to monitor antibody longevity and for tracking viral clearance in infected persons respectively, as well as provide information for epidemiological studies. On top of these tests, healthcare providers may use other ancillary tests, like CT scans, to provide insight for treatment plans for patients.

Most treatment approaches alleviate disease symptoms, and as the virus is still new with vast symptoms, there are a variety of therapeutics and ongoing clinical trials. Currently the FDA has approved remdesivir as well as given EUA to the use of the combination of remdesivir/baricitinib, and monoclonal antibodies bamlanivimab, bamlanivimab/ etesevimab, and casirivimab/imdevimab. Other therapeutic methods in trial include the suppression of host receptors like ACE2 and GRP78. ACE2 levels are regulated through vitamin $\mathrm{D}$ and calcitriol and can be suppressed with typical ACE2 inhibitors like enalapril. TMPRSS2 is a co-protein utilized by SARS-CoV-2 alongside ACE2 in infection, and so drugs that target TMPRSS2 like camostat mesylate are also under study. Monoclonal antibodies similar to bamlanivimab, bamlanivimab/etesevimab, and casirivimab/imdevimab are undergoing clinical trials and are of interest as they can work both as treatment as well as preventive therapeutics through their ability to recognize SARS-CoV-2 proteins, but also host proteins that are associated with SARS-CoV-2 pathogenesis. Following this train of thought, some studies are looking at suppressing the immune response to prevent cytokine storms and the damage they cause. Anti-inflammatory baricitinib has been approved for emergency use in combination with anti-viral remdesivir. Other anti-inflammatory therapeutics are under study including some that have been approved for other diseases (i.e., tocilizumab) as well as new anti-inflammatory therapies (i.e., IVIG). Convalescent plasma from recovered 
SARS-CoV-2-infected patients is also under investigation as it provides antibodies that can help neutralize the viral infection and lead to viral clearance. Finally, stem cell therapy could also aid in recovery as transplanted MSCs have been shown to improve patient outcomes.

To prevent disease transmission, there are currently 3 vaccines approved by the FDA for emergency use in the USA, produced by Johnson and Johnson, Pfizer, and Moderna. Both the Pfizer and Moderna vaccines require a doubledose injection of mRNA, while the Johnson and Johnson is a single-dose adenovirus vaccine, but all three target SARS-CoV-2 spike protein. Although these three vaccines are across headlines as they are approved, there are many other vaccines that are under trial including DNA vaccines, live attenuated vaccines, and inactivated vaccines.

Although there is still much to be studied about this virus, scientists have come a long way in a year. However, with new strains emerging and transmission rates rising, it is clear that the fight is not over, and that studies investigating all aspects of SARS-CoV-2 must continue.

Acknowledgements We thank all members of the Kashanchi laboratory, especially Gwen Cox.

Author contribution Conceptualization: Pooja Khatkar, Catherine DeMarino, and Daniel O. Pinto; introduction: Pooja Khatkar; pathology: Daniel O. Pinto, Gifty A. Mensah, and Anastasia Williams; diagnostics: Anastasia Williams; therapeutics: Sarah Al Sharif, Heather Branscome, and Catherine DeMarino; drafting: Anastasia Williams; critical revision: Anastasia Williams, Gifty A. Mensah, and Heather Branscome; supervision: Fatah Kashanchi.

Funding This review paper was supported by National Institutes of Health (NIH) Grants (AI078859, AI074410, AI127351-01, AI043894, and NS099029 to FK).

\section{Declarations}

Competing interests The authors declare no competing interests.

\section{References}

Abdel-Mannan O, Eyre M, Lobel U, Bamford A, Eltze C, Hameed B, Hemingway C, Hacohen Y (2020) Neurologic and radiographic findings associated with COVID-19 infection in children. JAMA Neurol 77(11):1-6. https://doi.org/10.1001/jamaneurol.2020. 2687

Abduljabbar T, Alhamdan RS, Al Deeb M, AlAali KA, Vohra F (2020) Association of salivary content alteration and early ageusia symptoms in COVID-19 infections: a systemic review. Eur J Dent 14(S 01):S152-S158. https://doi.org/10.1055/s-0040-1716986

Ahn DG, Shin HJ, Kim MH, Lee S, Kim HS, Myoung J, Kim BT, Kim SJ (2020) Current status of epidemiology, diagnosis, therapeutics, and vaccines for novel coronavirus disease 2019 (COVID19). J Microbiol Biotechnol 30(3):313-324. https://doi.org/10. 4014/jmb.2003.03011
Allam L, Ghrifi F, Mohammed H, El Hafidi N, El Jaoudi R, El Harti J, Lmimouni B, Belyamani L, Ibrahimi A (2020) Targeting the GRP78-dependant SARS-CoV-2 cell entry by peptides and small molecules. Bioinform Biol Insights 14:1177932220965505. https://doi.org/10.1177/1177932220965505

Amanat F, Krammer F (2020) SARS-CoV-2 vaccines: status report. Immunity 52(4):583-589. https://doi.org/10.1016/j.immuni. 2020.03.007

Andrews MG, Mukhtar T, Eze UC, Simoneau CR, Perez Y, MostajoRadji MA, Wang S, Velmeshev D, Salma J, Kumar GR, Pollen AA, Crouch EE, Ott M, Kriegstein AR (2021) Tropism of SARSCoV-2 for developing human cortical astrocytes. bioRxiv. https:// doi.org/10.1101/2021.01.17.427024

Arabi YM, Mandourah Y, Al-Hameed F, Sindi AA, Almekhlafi GA, Hussein MA, Jose J, Pinto R, Al-Omari A, Kharaba A, Almotairi A, Al Khatib K, Alraddadi B, Shalhoub S, Abdulmomen A, Qushmaq I, Mady A, Solaiman O, Al-Aithan AM, Al-Raddadi R, Ragab A, Balkhy HH, Al Harthy A, Deeb AM, Al Mutairi H, Al-Dawood A, Merson L, Hayden FG, Fowler RA; Saudi Critical Care Trial Group (2018) Corticosteroid therapy for critically ill patients with middle east respiratory syndrome. Am J Respir Crit Care Med 197(6):757-767. https://doi.org/10.1164/rccm.201706-1172OC

Asmussen S, Ito H, Traber DL, Lee JW, Cox RA, Hawkins HK, McAuley DF, McKenna DH, Traber LD, Zhuo H, Wilson J, Herndon DN, Prough DS, Liu KD, Matthay MA, Enkhbaatar P (2014) Human mesenchymal stem cells reduce the severity of acute lung injury in a sheep model of bacterial pneumonia. Thorax 69(9):819-825

Atluri S, Manchikanti L, Hirsch JA (2020) Expanded umbilical cord mesenchymal stem cells (uc-mscs) as a therapeutic strategy in managing critically ill COVID-19 patients: the case for compassionate use. Pain Physician 23(2):E71-E83

Baig AM, Khaleeq A, Ali U, Syeda H (2020) Evidence of the COVID19 virus targeting the CNS: Tissue distribution, host-virus interaction, and proposed neurotropic mechanisms. ACS Chem Neurosci 11(7):995-998. https://doi.org/10.1021/acschemneuro. 0c00122

Baig AM (2020) Deleterious outcomes in long-hauler COVID-19: the effects of SARS-CoV-2 on the CNS in chronic COVID syndrome. ACS Chem Neurosci 11(24):4017-4020. https://doi.org/ 10.1021/acschemneuro.0c00725

Baig AM (2021) Chronic COVID syndrome: need for an appropriate medical terminology for long-COVID and COVID long-haulers. J Med Virol 93(5):2555-2556. https://doi.org/10.1002/jmv.26624

Baraniak PR, McDevitt TC (2010) Stem cell paracrine actions and tissue regeneration. Regen Med 5(1):121-143. https://doi.org/ 10.2217/rme.09.74

Barrantes FJ (2020) Central nervous system targets and routes for SARSCoV-2: current views and new hypotheses. ACS Chem Neurosci 11(18):2793-2803. https://doi.org/10.1021/acschemneuro. $0 \mathrm{c} 00434$

Bergmann CC, Lane TE, Stohlman SA (2006) Coronavirus infection of the central nervous system: host-virus stand-off. Nat Rev Microbiol 4(2):121-132. https://doi.org/10.1038/nrmicro1343

Bernstein HG, Dobrowolny H, Keilhoff G, Steiner J (2018) Dipeptidyl peptidase IV, which probably plays important roles in Alzheimer disease (AD) pathology, is upregulated in AD brain neurons and associates with amyloid plaques. Neurochem Int 114:55-57. https://doi.org/10.1016/j.neuint.2018.01.005

Bojkova D, Bechtel M, McLaughlin KM, McGreig JE, Klann K, Bellinghausen C, Rohde G, Jonigk D, Braubach P, Ciesek S, Münch C, Wass MN, Michaelis M, Cinatl J Jr (2020) Aprotinin inhibits SARS-CoV-2 replication. Cells 9(11):2377. https:// doi.org/10.3390/cells9112377

Bombardini T, Picano E (2020) Angiotensin-Converting Enzyme 2 as the molecular bridge between epidemiologic and clinical features 
of COVID-19. Can J Cardiol 36(5):784.e1-784.e2. https://doi. org/10.1016/j.cjca.2020.03.026

Boonacker E, Van Noorden CJ (2003) The multifunctional or moonlighting protein CD26/DPPIV. Eur J Cell Biol 82(2):53-73. https://doi.org/10.1078/0171-9335-00302

Branscome H, Paul S, Khatkar P, Kim Y, Barclay RA, Pinto DO, Yin D, Zhou W, Liotta LA, El-Hage N, Kashanchi F (2020) Stem cell extracellular vesicles and their potential to contribute to the repair of damaged CNS cells. J Neuroimmune Pharmacol 15(3):520-537. https://doi.org/10.1007/s11481-019-09865-y. HTLV-1

Breining P, Frølund AL, Højen JF, Gunst JD, Staerke NB, Saedder E, Cases-Thomas M, Little P, Nielsen LP, Søgaard OS, Kjolby M (2021) Camostat mesylate against SARS-CoV-2 and COVID19-Rationale, dosing and safety. Basic Clin Pharmacol Toxicol 128(2):204-212. https://doi.org/10.1111/bcpt.13533

Brendish NJ, Poole S, Naidu VV, Mansbridge CT, Norton NJ, Wheeler H, Presland L, Kidd S, Cortes NJ, Borca F, Phan H, Babbage G, Visseaux B, Ewings S, Clark TW (2020) Clinical impact of molecular point-of-care testing for suspected COVID-19 in hospital (COV-19POC): a prospective, interventional, nonrandomised, controlled study. Lancet Respir Med 8(12):11921200. https://doi.org/10.1016/S2213-2600(20)30454-9

Broughton JP, Deng X, Yu G, Fasching CL, Servellita V, Singh J, Miao X, Streithorst JA, Granados A, Sotomayor-Gonzalez A, Zorn K, Gopez A, Hsu E, Gu W, Miller S, Pan CY, Guevara H, Wadford DA, Chen JS, Chiu CY (2020) CRISPR-Cas12-based detection of SARS-CoV-2. Nat Biotechnol 38(7):870-874. https://doi.org/ 10.1038/s41587-020-0513-4

Center for Disease Control and Prevention (2020a) Test for COVID19 Only. In: COVID-19. Available via: https://www.cdc.gov/ coronavirus/2019-ncov/lab/virus-requests.html. Accessed December 152020

Center for Disease Control and Prevention (2020b) Vaccine testing and the approval process. In: Vaccines \& Immunizations. Available via: https://www.cdc.gov/vaccines/basics/test-approve.html. Accessed May 52020

Center for Disease Control and Prevention (2021) Post-COVID Conditions. Available via: https://www.cdc.gov/coronavirus/2019ncov/long-term-effects.html. Accessed May 52021

Ceylan RF, Ozkan B, Mulazimogullari E (2020) Historical evidence for economic effects of COVID-19. Eur J Health Econ 21(6):817823. https://doi.org/10.1007/s10198-020-01206-8

Chafekar A, Fielding BC (2018) MERS-CoV: Understanding the latest human coronavirus threat. Viruses 10(2):93. https://doi.org/10. 3390/v10020093

Chan PK, To KF, Lo AW, Cheung JL, Chu I, Au FW, Tong JH, Tam JS, Sung JJ, Ng HK (2004) Persistent infection of SARS coronavirus in colonic cells in vitro. J Med Virol 74(1):1-7. https://doi.org/ 10.1002/jmv. 20138

Chan RW, Chan MC, Agnihothram S, Chan LL, Kuok DI, Fong JH, Guan Y, Poon LL, Baric RS, Nicholls JM, Peiris JS (2013) Tropism of and innate immune responses to the novel human betacoronavirus lineage $\mathrm{C}$ virus in human ex vivo respiratory organ cultures. J Virol 87(12):6604-6614. https://doi.org/10.1128/JVI. 00009-13

Chang SC (2005) Clinical findings, treatment and prognosis in patients with severe acute respiratory syndrome (SARS). J Chin Med Assoc 68(3):106-107. https://doi.org/10.1016/S1726-4901(09) 70229-1

Channappanavar R, Fehr AR, Vijay R, Mack M, Zhao J, Meyerholz DK, Perlman S (2016) Dysregulated type I interferon and inflammatory monocyte-macrophage responses cause lethal pneumonia in SARS-CoV-infected mice. Cell Host Microbe 19(2):181-193. https://doi.org/10.1016/j.chom.2016.01.007
Chen L, Xiong J, Bao L, Shi Y (2020a) Convalescent plasma as a potential therapy for COVID-19. Lancet Infect Dis 20(4):398400. https://doi.org/10.1016/S1473-3099(20)30141-9

Chen M, Reed RR, Lane AP (2017) Acute inflammation regulates neuroregeneration through the NF- $\mathrm{KB}$ pathway in olfactory epithelium. Proc Natl Acad Sci USA 114(30):8089-8094. https:// doi.org/10.1073/pnas.1620664114

Chen N, Zhou M, Dong X, Qu J, Gong F, Han Y, Qiu Y, Wang J, Liu Y, Wei Y, Xia J, Yu T, Zhang X, Zhang L (2020b) Epidemiological and clinical characteristics of 99 cases of 2019 novel coronavirus pneumonia in Wuhan, China: a descriptive study. Lancet 395(10223):507-513. https://doi.org/10.1016/S01406736(20)30211-7

Cheng MP, Papenburg J, Desjardins M, Kanjilal S, Quach C, Libman M, Dittrich S, Yansouni CP (2020) Diagnostic testing for severe acute respiratory syndrome-related coronavirus 2 : A narrative review. Ann Intern Med 172(11):726-734. https:// doi.org/10.7326/M20-1301

Cheng Y, Wong R, Soo YO, Wong WS, Lee CK, Ng MH, Chan P, Wong KC, Leung CB, Cheng G (2005) Use of convalescent plasma therapy in SARS patients in Hong Kong. Eur J Clin Microbiol Infect Dis 24(1):44-46. https://doi.org/10.1007/ s10096-004-1271-9

Cherry JD (2004) The chronology of the 2002-2003 SARS mini pandemic. Paediatr Respir Rev 5(4):262-269. https://doi.org/ 10.1016/j.prrv.2004.07.009

Chien JY, Hsueh PR, Cheng WC, Yu CJ, Yang PC (2006) Temporal changes in cytokine/chemokine profiles and pulmonary involvement in severe acute respiratory syndrome. Respirology 11(6):715-722. https://doi.org/10.1111/j.1440-1843.2006. 00942.x

Chun S, Chung CR, Ha YE, Han TH, Ki CS, Kang ES, Park JK, Peck KR, Cho D (2016) Possible transfusion-related acute lung injury following convalescent plasma transfusion in a patient with Middle East respiratory syndrome. Ann Lab Med 36(4):393-395. https://doi.org/10.3343/alm.2016.36.4.393

Chung JY, Thone MN, Kwon YJ (2020) COVID-19 vaccines: the status and perspectives in delivery points of view. Adv Drug Deliv Rev 170:1-25. https://doi.org/10.1016/j.addr.2020.12.011

Clinical Trials (2021) Find a study. NIH: NLM. Available via: https:// clinicaltrials.gov/ct2/home. Accessed January 132021

Corman VM, Ithete NL, Richards LR, Schoeman MC, Preiser W, Drosten C, Drexler JF (2014) Rooting the phylogenetic tree of middle east respiratory syndrome coronavirus by characterization of a conspecific virus from an African bat. J Virol 88(19):1129711303. https://doi.org/10.1128/JVI.01498-14

Coronaviridae Study Group of the International Committee on Taxonomy of Viruses (2020) The species severe acute respiratory syndrome-related coronavirus: classifying 2019-nCoV and naming it SARS-CoV-2. Nat Microbiol 5(4):536-544. https://doi.org/ 10.1038/s41564-020-0695-z

Coughlin MM, Prabhakar BS (2012) Neutralizing human monoclonal antibodies to severe acute respiratory syndrome coronavirus: target, mechanism of action, and therapeutic potential. Rev Med Virol 22(1):2-17. https://doi.org/10.1002/rmv.706

Cruz FF, Rocco PRM (2017) Stem-cell extracellular vesicles and lung repair. Stem Cell Investig 4:78

Curley GF, Jerkic M, Dixon S, Hogan G, Masterson C, O'Toole D, Devaney J, Laffey JG (2017) Cryopreserved, xeno-free human umbilical cord mesenchymal stromal cells reduce lung injury severity and bacterial burden in rodent escherichia coliinduced acute respiratory distress syndrome. Crit Care Med 45(2): e202-e212

Davies J, Randeva HS, Chatha K, Hall M, Spandidos DA, Karteris E, Kyrou I (2020) Neuropilin-1 as a new potential SARS-CoV-2 
infection mediator implicated in the neurologic features and central nervous system involvement of COVID-19. Mol Med Rep 22(5):4221-4226. https://doi.org/10.3892/mmr.2020.11510

de Alwis R, Chen S, Gan ES, Ooi EE (2020) Impact of immune enhancement on Covid-19 polyclonal hyperimmune globulin therapy and vaccine development. EBioMedicine 55:102768. https://doi.org/10.1016/j.ebiom.2020.102768

de Souza Luna LK, Heiser V, Regamey N, Panning M, Drexler JF, Mulangu S, Poon L, Baumgarte S, Haijema BJ, Kaiser L, Drosten C (2007) Generic detection of coronaviruses and differentiation at the prototype strain level by reverse transcription-PCR and nonfluorescent low-density microarray. J Clin Microbiol 45(3):1049-1052. https://doi.org/10.1128/JCM.02426-06

Delamater PL, Street EJ, Leslie TF, Yang YT, Jacobsen KH (2019) Complexity of the basic reproduction number $\left(\mathrm{R}_{0}\right)$. Emerg Infect Dis 25(1):1-4. https://doi.org/10.3201/eid2501.171901

Deng H, Sun C, Sun Y, Li H, Yang L, Wu D, Gao Q, Jiang X (2018) Lipid, protein, and microRNA composition within mesenchymal stem cell-derived exosomes. Cell Reprogram 20(3):178-186

Ding Y, He L, Zhang Q, Huang Z, Che X, Hou J, Wang H, Shen H, Qiu L, Li Z, Geng J, Cai J, Han H, Li X, Kang W, Weng D, Liang P, Jiang S (2004) Organ distribution of severe acute respiratory syndrome (SARS) associated coronavirus (SARS-CoV) in SARS patients: implications for pathogenesis and virus transmission pathways. J Pathol 203(2):622-630. https://doi.org/10.1002/path. 1560

Ding Y, Wang H, Shen H, Li Z, Geng J, Han H, Cai J, Li X, Kang W, Weng D, Lu Y, Wu D, He L, Yao K (2003) The clinical pathology of severe acute respiratory syndrome (SARS): a report from China. J Pathol 200(3):282-289. https://doi.org/10.1002/path. 1440

Dong M, Zhang J, Ma X, Tan J, Chen L, Liu S, Xin Y, Zhuang L (2020) ACE2, TMPRSS2 distribution and extrapulmonary organ injury in patients with COVID-19. Biomed Pharmacother 131:110678. https://doi.org/10.1016/j.biopha.2020.110678

Duan HQ, Wu QL, Yao X, Fan BY, Shi HY, Zhao CX, Zhang Y, Li B, Sun C, Kong XH, Zhou XF, Feng SQ (2018) Nafamostat mesilate attenuates inflammation and apoptosis and promotes locomotor recovery after spinal cord injury. CNS Neurosci Ther 24(5):429-438. https://doi.org/10.1111/cns.12801

Eliezer M, Hautefort C, Hamel AL, Verillaud B, Herman P, Houdart E, Eloit C (2020) Sudden and complete olfactory loss of function as a possible symptom of COVID-19. JAMA Otolaryngol Head Neck Surg 146(7):674-675. https://doi.org/10.1001/ jamaoto.2020.0832

Ellul MA, Benjamin L, Singh B, Lant S, Michael BD, Easton A, Kneen R, Defres S, Sejvar J, Solomon T (2020) Neurological associations of COVID-19. Lancet Neurol 19(9):767-783. https://doi. org/10.1016/S1474-4422(20)30221-0

Esbin MN, Whitney ON, Chong S, Maurer A, Darzacq X, Tjian R (2020) Overcoming the bottleneck to widespread testing: a rapid review of nucleic acid testing approaches for COVID-19 detection. RNA 26(7):771-783. https://doi.org/10.1261/rna.076232. 120

Fehr AR, Perlman S (2015) Coronaviruses: an overview of their replication and pathogenesis. Methods Mol Biol 1282:1-23. https:// doi.org/10.1007/978-1-4939-2438-7_1

Festa M, Sansone C, Brunet C, Crocetta F, Di Paola L, Lombardo M, Bruno A, Noonan DM, Albini A (2020) Cardiovascular active peptides of marine origin with ACE inhibitory activities: potential role as anti-hypertensive drugs and in prevention of SARSCoV-2 infection. Int J Mol Sci 21(21):8364. https://doi.org/10. 3390/ijms 21218364

Food and Drug Administration (2020a) Coronavirus (COVID-19) update: FDA authorizes drug combination for treatment of COVID-19. In: Press Announcements. Available via: https:// www.fda.gov/news-events/press-announcements/coronaviruscovid-19-update-fda-authorizes-drug-combination-treatmentcovid-19. Accessed on January 132021

Food and Drug Administration (2020b) Coronavirus (COVID-19) update: FDA authorizes monoclonal antibody for treatment of COVID-19. In: Press Announcements. Available via: https:// www.fda.gov/news-events/press-announcements/coronaviruscovid-19-update-fda-authorizes-monoclonal-antibody-treatmentcovid-19. Accessed on January 132021

Food and Drug Administration (2021a) Coronavirus (COVID-19) update: FDA authorizes monoclonal antibodies for treatment of COVID-19. In: Press Announcements. Availabile via: https://www.fda.gov/news-events/press-announcements/ coronavirus-covid-19-update-fda-authorizes-monoclonalantibodies-treatment-covid-19-0. Accessed on April 82021

Food and Drug Administration (2021b) Coronavirus (COVID-19) update: FDA issues emergency authorization for they symbiotica COVID-19 self-collected antibody test system. In: Press Announcements. Available via : https://www.fda.gov/newsevents/press-announcements/coronavirus-covid-19-update-fdaissues-emergency-use-authorization-symbiotica-covid-19-self. Accessed on April 82021

Food and Drug Administration (2021c) In vitro diagnostics EUAs serology and other adaptive immune response tests for SARSCoV-2. In: Coronavirus disease 2019 (COVID-19) emergency use authorizations for medical devices. Available via : https:// www.fda.gov/medical-devices/coronavirus-disease-2019covid-19-emergency-use-authorizations-medical-devices/invitro-diagnostics-euas-serology-and-other-adaptive-immuneresponse-tests-sars-cov-2. Accessed April 82021

Food and Drug Administration (2021d) In vitro diagnostics EUAs molecular diagnostic tests for SARS-CoV-2. In: Coronavirus disease 2019 (COVID-19) emergency use authorizations for medical devices. Available via: https://www.fda.gov/medicaldevices/coronavirus-disease-2019-covid-19-emergency-useauthorizations-medical-devices/in-vitro-diagnostics-euasmolecular-diagnostic-tests-sars-cov-2. Accessed April 82021

Food and Drug Administration (2021e) Recommendations for investigational COVID-19 convalescent plasma. In: Investigational New Drug IIND) or Device Exemption (IDE) Process (CBER). Available via : https://www.fda.gov/vaccines-blood-biologics/ investigational-new-drug-ind-or-device-exemption-ideprocess-cber/recommendations-investigational-covid-19convalescent-plasma. Accessed on April 82021

Foundation for Innovative New Diagnostics (2021) SARS-CoV-2 diagnostic pipeline. In: Diagnostics \& Testing. Available via: https:// www.finddx.org/test-directory/. Accessed April 82021

Gaddam RR, Chambers S, Bhatia M (2014) ACE and ACE2 in inflammation: a tale of two enzymes. Inflamm Allergy Drug Targets 13(4):224 234. https://doi.org/10.2174/1871528113666140713164506

Gao F, Chiu SM, Motan DA, Zhang Z, Chen L, Ji HL, Tse HF, Fu QL, Lian Q (2016) Mesenchymal stem cells and immunomodulation: current status and future prospects. Cell Death Dis 7:e2062. https://doi.org/10.1038/cddis.2015.327

Gautier JF, Ravussin Y (2020) A new symptom of COVID-19: loss of taste and smell. Obesity (silver Spring) 28(5):848. https://doi. org/10.1002/oby.22809

Ghali GZ, Ghali MGZ (2020) Nafamostat mesylate attenuates the pathophysiologic sequelae of neurovascular ischemia. Neural Regen Res 15(12):2217-2234. https://doi.org/10.4103/16735374.284981

Gilani S, Roditi R, Naraghi M (2020) COVID-19 and anosmia in Tehran. Iran Med Hypotheses 141:109757. https://doi.org/10. 1016/j.mehy.2020.109757

Gorabi AM, Kiaie N, Barreto GE, Read MI, Tafti HA, Sahebkar A (2019) The therapeutic potential of mesenchymal stem 
cell-derived exosomes in treatment of neurodegenerative diseases. Mol Neurobiol 56(12):8157-8167. https://doi.org/10. 1007/s12035-019-01663-0

Gözen ED, Aliyeva C, Tevetoğlu F, Karaali R, Balkan İI, Yener HM, Özdoğan HA (2020) Evaluation of olfactory function with objective tests in COVID-19-positive patients: a crosssectional study. Ear Nose Throat J 25:145561320975510. https://doi.org/10.1177/0145561320975510

Graham EL, Clark JR, Orban ZS, Lim PH, Szymanski AL, Taylor C, DiBiase RM, Jia DT, Balabanov R, Ho SU, Batra A, Liotta EM, Koralnik IJ (2021) Persistent neurologic symptoms and cognitive dysfunction in non-hospitalized Covid-19 "long haulers". Ann Clin Transl Neurol 8(5):1073-1085. https://doi.org/ $10.1002 / \mathrm{acn} 3.51350$

Gralinski LE, Baric RS (2015) Molecular pathology of emerging coronavirus infections. J Pathol 235(2):185-195. https://doi. org/10.1002/path.4454

Griffith JF, Antonio GE, Kumta SM, Hui DS, Wong JK, Joynt GM, Wu AK, Cheung AY, Chiu KH, Chan KM, Leung PC, Ahuja AT (2005) Osteonecrosis of hip and knee in patients with severe acute respiratory syndrome treated with steroids. Radiology 235(1):168-175. https://doi.org/10.1148/radiol. 2351040100

Groiss SJ, Balloff C, Elben S, Brandenburger T, Müttel T, KindgenMilles D, Vollmer C, Feldt T, Kunstein A, Ole Jensen BE, Hartung HP, Schnitzler A, Albrecht P (2020) Prolonged neuropsychological deficits, central nervous system involvement, and brain stem affection after COVID-19-A case series. Front Neurol 11:574004. https://doi.org/10.3389/fneur.2020. 574004

Gu J, Gong E, Zhang B, Zheng J, Gao Z, Zhong Y, Zou W, Zhan J, Wang S, Xie Z, Zhuang H, Wu B, Zhong H, Shao H, Fang W, Gao D, Pei F, Li X, He Z, Xu D, Shi X, Anderson VM, Leong AS (2005) Multiple organ infection and the pathogenesis of SARS. J Exp Med 3:415-424. https://doi.org/10.1084/jem.20050828

Guan WJ, Ni ZY, Hu Y, Liang WH, Ou CQ, He JX, Liu L, Shan H, Lei CL, Hui DSC, Du B, Li LJ, Zeng G, Yuen KY, Chen RC, Tang CL, Wang T, Chen PY, Xiang J, Li SY, Wang JL, Liang ZJ, Peng YX, Wei L, Liu Y, Hu YH, Peng P, Wang JM, Liu JY, Chen Z, Li G, Zheng ZJ, Qiu SQ, Luo J, Ye CJ, Zhu SY, Zhong NS; China Medical Treatment Expert Group for Covid-19 (2020) Clinical characteristics of coronavirus disease 2019 in China. N Engl J Med 382(18):1708-1720. https://doi.org/10.1056/ NEJMoa2002032

Guo J, Jiang D, Feng S, Ren C, Guo J (2020a) $\mu$-NMR at the point of care testing. Electrophoresis 41(5-6):319-327. https://doi.org/ 10.1002/elps.201900329

Guo YR, Cao QD, Hong ZS, Tan YY, Chen SD, Jin HJ, Tan KS, Wang DY, Yan Y (2020b) The origin, transmission and clinical therapies on coronavirus disease 2019 (COVID-19) outbreak - an update on the status. Mil Med Res 7(1):11. https://doi.org/10. 1186/s40779-020-00240-0

Gupta N, Su X, Popov B, Lee JW, Serikov V, Matthay MA (2007) Intrapulmonary delivery of bone marrow-derived mesenchymal stem cells improves survival and attenuates endotoxin-induced acute lung injury in mice. J Immunol 179(3):1855-1863. https:// doi.org/10.4049/jimmunol.179.3.1855

Haga S, Yamamoto N, Nakai-Murakami C, Osawa Y, Tokunaga K, Sata T, Yamamoto N, Sasazuki T, Ishizaka Y (2008) Modulation of TNF-alpha-converting enzyme by the spike protein of SARS$\mathrm{CoV}$ and ACE2 induces TNF-alpha production and facilitates viral entry. Proc Natl Acad Sci USA 105(22):7809-7814. https:// doi.org/10.1073/pnas.0711241105

Hamming I, Timens W, Bulthuis ML, Lely AT, Navis G, van Goor H (2004) Tissue distribution of ACE2 protein, the functional receptor for SARS coronavirus. A first step in understanding SARS pathogenesis. J Pathol 203(2):631-637. https://doi.org/10.1002/ path. 1570

Hardick J, Metzgar D, Risen L, Myers C, Balansay M, Malcom T, Rothman R, Gaydos C (2018) Initial performance evaluation of a spotted array Mobile Analysis Platform (MAP) for the detection of influenza A/B, RSV, and MERS coronavirus. Diagn Microbiol Infect Dis 91(3):245-247. https://doi.org/10.1016/j.diagmicrobio.2018.02.011

Harmer D, Gilbert M, Borman R, Clark KL (2002) Quantitative mRNA expression profiling of ACE 2, a novel homologue of angiotensin converting enzyme. FEBS Lett 532(1-2):107-110. https://doi.org/ 10.1016/s0014-5793(02)03640-2

Harrell CR, Jovicic BP, Djonov V, Volarevic V (2020) Therapeutic potential of mesenchymal stem cells and their secretome in the treatment of SARS-CoV-2-induced acute respiratory distress syndrome. Anal Cell Pathol (amst) 2020:1939768. https://doi. org/10.1155/2020/1939768

Harrell CR, Sadikot R, Pascual J, Fellabaum C, Jankovic MG, Jovicic N, Djonov V, Arsenijevic N, Volarevic V (2019) Mesenchymal stem cell-based therapy of inflammatory lung diseases: current understanding and future perspectives. Stem Cells Int 2019:4236973. https://doi.org/10.1155/2019/4236973

Harris VK, Yan QJ, Vyshkina T, Sahabi S, Liu X, Sadiq SA (2012) Clinical and pathological effects of intrathecal injection of mesenchymal stem cell-derived neural progenitors in an experimental model of multiple sclerosis. J Neurol Sci 313(1-2):167-177. https://doi.org/10.1016/j.jns.2011.08.036

Hirotsu Y, Maejima M, Shibusawa M, Amemiya K, Nagakubo Y, Hosaka K, Sueki H, Hayakawa M, Mochizuki H, Tsutsui T, Kakizaki Y, Miyashita Y, Omata M (2020) Analysis of a persistent viral shedding patient infected with SARS-CoV-2 by RT-qPCR FilmArray Respiratory Panel v2.1 and antigen detection. J Infect Chemother 27(2):406-409. https://doi.org/10.1016/j.jiac.2020. 10.026

Hirotsu Y, Maejima M, Shibusawa M, Nagakubo Y, Hosaka K, Amemiya K, Sueki H, Hayakawa M, Mochizuki H, Tsutsui T, Kakizaki Y, Miyashita Y, Yagi S, Kojima S, Omata M (2020b) Comparison of automated SARS-CoV-2 antigen test for COVID-19 infection with quantitative RT-PCR using 313 nasopharyngeal swabs, including from seven serially followed patients. Int J Infect Dis 99:397-402. https://doi.org/10.1016/j.ijid.2020.08.029

Hoang TN, Pino M, Boddapati AK, Viox EG, Starke CE, Upadhyay AA, Gumber S, Nekorchuk M, Busman-Sahay K, Strongin Z, Harper JL, Tharp GK, Pellegrini KL, Kirejczyk S, Zandi K, Tao S, Horton TR, Beagle EN, Mahar EA, Lee MYH, Cohen J, Jean SM, Wood JS, Connor-Stroud F, Stammen RL, Delmas OM, Wang S, Cooney KA, Sayegh MN, Wang L, Filev PD, Weiskopf D, Silvestri G, Waggoner J, Piantadosi A, Kasturi SP, Al-Shakhshir H, Ribeiro SP, Sekaly RP, Levit RD, Estes JD, Vanderford TH, Schinazi RF, Bosinger SE, Paiardini M (2021) Baricitinib treatment resolves lower-airway macrophage inflammation and neutrophil recruitment in SARS-CoV-2-infected rhesus macaques. Cell 184(2):460-475.e21. https://doi.org/10. 1016/j.cell.2020.11.007

Hocke AC, Becher A, Knepper J, Peter A, Holland G, Tönnies M, Bauer TT, Schneider P, Neudecker J, Muth D, Wendtner CM, Rückert JC, Drosten C, Gruber AD, Laue M, Suttorp N, Hippenstiel S, Wolff T (2013) Emerging human middle east respiratory syndrome coronavirus causes widespread infection and alveolar damage in human lungs. Am J Respir Crit Care Med 188(7):882-886. https://doi.org/10.1164/rccm.201305-0954LE

Hoffmann M, Kleine-Weber H, Schroeder S, Krüger N, Herrler T, Erichsen S, Schiergens TS, Herrler G, Wu NH, Nitsche A, Müller MA, Drosten C, Pöhlmann S (2020) SARS-CoV-2 cell entry depends on ACE2 and TMPRSS2 and is blocked by a clinically proven protease inhibitor. Cell 181(2):271-280.e8. https://doi.org/10.1016/j.cell.2020.02.052 
Hojyo S, Uchida M, Tanaka K, Hasebe R, Tanaka Y, Murakami M, Hirano T (2020) How COVID-19 induces cytokine storm with high mortality. Inflamm Regener 40:37. https://doi.org/ 10.1186/s41232-020-00146-3

Hu B, Guo H, Zhou P, Shi Z-1 (2020) Characteristics of SARS-CoV-2 and COVID-19. Nat Rev Microbiol 6:1-14. https://doi.org/10. 1038/s41579-020-00459-7

Huang C, Wang Y, Li X, Ren L, Zhao J, Hu Y, Zhang L, Fan G, Xu J, Gu X, Cheng Z, Yu T, Xia J, Wei Y, Wu W, Xie X, Yin W, Li H, Liu M, Xiao Y, Gao H, Guo L, Xie J, Wang G, Jiang R, Gao Z, Jin Q, Wang J, Cao B (2020) Clinical features of patients infected with 2019 novel coronavirus in Wuhan. China Lancet 395(10223):497-506. https://doi.org/10.1016/S0140-6736(20) 30183-5

Huang Y, Pinto MD, Borelli JL, Mehrabadi MA, Abrihim H, Dutt N, Lambert N, Nurmi EL, Chakraborty R, Rahmani AM, Downs CA (2021) COVID symptoms, symptom clusters, and predictors for becoming a long-hauler: Looking for clarity in the haze of the pandemic. medRxiv. https://doi.org/10.1101/2021.03.03. 21252086

Hung IFN, To KKW, Lee CK, Lee KL, Yan WW, Chan K, Chan WM, Ngai CW, Law KI, Chow FL, Liu R, Lai KY, Lau CCY, Liu SH, Chan KH, Lin CK, Yuen KY (2013) Hyperimmune IV immunoglobulin treatment: a multicenter double-blind randomized controlled trial for patients with severe 2009 influenza A(H1N1) infection. Chest 144(2):464-473. https://doi.org/10.1378/chest. 12-2907

Imai Y, Kuba K, Rao S, Huan Y, Guo F, Guan B, Yang P, Sarao R, Wada T, Leong-Poi H, Crackower MA, Fukamizu A, Hui CC, Hein L, Uhlig S, Slutsky AS, Jiang C, Penninger JM (2005) Angiotensin-converting enzyme 2 protects from severe acute lung failure. Nature 436(7047):112-116. https://doi.org/10.1038/ nature 03712

Jiao L, Yang Y, Yu W, Zhao Y, Long H, Gao J, Ding K, Ma C, Li J, Zhao S, Wang H, Li H, Yang M, Xu J, Wang J, Yang J, Kuang D, Luo F, Qian X, Xu L, Yin B, Liu W, Liu H, Lu S, Peng X (2021) The olfactory route is a potential way for SARS-CoV-2 to invade the central nervous system of rhesus monkeys. Signal Transduct Target Ther 6(1):169. https://doi.org/10.1038/ s41392-021-00591-7

Jin Y, Lei C, Hu D, Dimitrov DS, Ying T (2017) Human monoclonal antibodies as candidate therapeutics against emerging viruses. Front Med 11(4):462-470. https://doi.org/10.1007/ s11684-017-0596-6

Johnson and Johnson (2021) Johnson \& Johnson COVID-19 vaccine authorized by U.S. FDA for emergency use - first single - shot vaccine in fight against global pandemic. Available via: https:// www.jnj.com/johnson-johnsoncovid-19-vaccine-authorizedby-u-s-fda-for-emergency-usefirst-single-shot-vaccine-in-fightagainst-globalpandemic. Accessed April 82021

Joo HS, Suh JH, Lee HJ, Bang ES, Lee JM (2020) Current knowledge and future perspectives on mesenchymal stem cell-derived exosomes as a new therapeutic agent. Int J Mol Sci 21(3):727

Kaly L, Rosner I (2012) Tocilizumab - a novel therapy for non-organspecific autoimmune diseases. Best Pract Res Clin Rheumatol 26(1):157-165. https://doi.org/10.1016/j.berh.2012.01.001

Katsuda T, Ochiya T (2015) Molecular signatures of mesenchymal stem cell-derived extracellular vesicle-mediated tissue repair. Stem Cell Res Ther 6:212

Kim K, Ko Y, Ko DS, Kim YH (2020) Prognostic significance of COVID-19 receptor ACE2 and recommendation for antihypertensive drug in renal cell carcinoma. Biomed Res Int 2020:2054376. https://doi.org/10.1155/2020/2054376

Kotani T, Masutani R, Suzuka T, Oda K, Makino S, Ii M (2017) Anti-inflammatory and anti-fibrotic effects of intravenous adipose-derived stem cell transplantation in a mouse model of bleomycin-induced interstitial pneumonia. Sci Rep 7(1):14608

Kuba K, Imai Y, Rao S, Gao H, Guo F, Guan B, Huan Y, Yang P, Zhang Y, Deng W, Bao L, Zhang B, Liu G, Wang Z, Chappell M, Liu Y, Zheng D, Leibbrandt A, Wada T, Slutsky AS, Liu D, Qin C, Jiang C, Penninger JM (2005) A crucial role of angiotensin converting enzyme 2 (ACE2) in SARS coronavirus-induced lung injury. Nat Med 11(8):875-879. https://doi.org/10.1038/nm1267

Kumar A, Faiq MA, Pareek V, Raza K, Narayan RK, Prasoon P, Kumar P, Kulandhasamy M, Kumari C, Kant K, Singh HN, Qadri R, Pandey SN, Kumar S (2020a) Relevance of SARS-CoV-2 related factors ACE2 and TMPRSS2 expressions in gastrointestinal tissue with pathogenesis of digestive symptoms, diabetesassociated mortality, and disease recurrence in COVID-19 patients. Med Hypotheses 144:110271. https://doi.org/10.1016/j. mehy.2020.110271

Kumar M, Taki K, Gahlot R, Sharma A, Dhangar K (2020b) A chronicle of SARS-CoV-2: Part-I - Epidemiology, diagnosis, prognosis, transmission and treatment. Sci Total Environ 10(734):139278. https://doi.org/10.1016/j.scitotenv.2020. 139278

Lai CC, Shih TP, Ko WC, Tang HJ, Hsueh PR (2020) Severe acute respiratory syndrome coronavirus 2 (SARS-CoV-2) and coronavirus disease-2019 (COVID-19): the epidemic and the challenges. Int J Antimicrob Agents 55(3):105924. https://doi.org/10.1016/j. ijantimicag.2020.105924

Lee CY, Lin RTP, Renia L, Ng LFP (2020) Serological approaches for COVID-19: epidemiologic perspective on surveillance and control. Front Immunol 11:879. https://doi.org/10.3389/fimmu. 2020.00879

Lee DW, Gardner R, Porter DL, Louis CU, Ahmed N, Jensen M, Grupp SA, Mackall CL (2014) Current concepts in the diagnosis and management of cytokine release syndrome. Blood 124(2):188195. https://doi.org/10.1182/blood-2014-05-552729

Lee JW, Fang X, Gupta N, Serikov V, Matthay MA (2009) Allogeneic human mesenchymal stem cells for treatment of $\mathrm{E}$ coli endotoxin-induced acute lung injury in the ex vivo perfused human lung. Proc Natl Acad Sci USA. 106(38):16357-16362. https:// doi.org/10.1073/pnas.0907996106

Lee N, Leo YS, Cao B, Chan PK, Kyaw WM, Uyeki TM, Tam WW, Cheung CS, Yung IM, Li H, Gu L, Liu Y, Liu Z, Qu J, Hui DS (2015) Neuraminidase inhibitors, superinfection and corticosteroids affect survival of influenza patients. Eur Respir J 45(6):1642-1652. https://doi.org/10.1183/09031936.00169714

Leng Z, Zhu R, Hou W, Feng Y, Yang Y, Han Q, Shan G, Meng F, Du D, Wang S, Fan J, Wang W, Deng L, Shi H, Li H, Hu Z, Zhang F, Gao J, Liu H, Li X, Zhao Y, Yin K, He X, Gao Z, Wang Y, Yang B, Jin R, Stambler I, Lim LW, Su H, Moskalev A, Cano A, Chakrabarti S, Min KJ, Ellison-Hughes G, Caruso C, Jin K, Zhao RC (2020) Transplantation of ACE2- mesenchymal stem cells improves the outcome of patients with COVID-19 pneumonia. Aging Dis 11(2):216-228. https://doi.org/10.14336/AD. 2020.0228

Li C, Wang J, Fang Y, Liu Y, Chen T, Sun H, Zhou XF, Liao H (2016) Nafamostat mesilate improves function recovery after stroke by inhibiting neuroinflammation in rats. Brain Behav Immun 56:230-245. https://doi.org/10.1016/j.bbi.2016.03.019

Li F, Li W, Farzan M, Harrison SC (2005) Structure of SARS coronavirus spike receptor-binding domain complexed with receptor. Science 309(5742):1864-1868. https://doi.org/10.1126/science

Li H, Xue Q, Xu X (2020a) Involvement of the nervous system in SARS-CoV-2 infection. Neurotox Res 38(1):1-7. https://doi.org/ 10.1007/s12640-020-00219-8

Li MY, Li L, Zhang Y, Wang XS (2020b) Expression of the SARSCoV-2 cell receptor gene ACE2 in a wide variety of human 
tissues. Infect Dis Poverty 9(1):45. https://doi.org/10.1186/ s40249-020-00662-x

Li W, Moore MJ, Vasilieva N, Sui J, Wong SK, Berne MA, Somasundaran M, Sullivan JL, Luzuriaga K, Greenough TC, Choe H, Farzan M (2003) Angiotensin-converting enzyme 2 is a functional receptor for the SARS coronavirus. Nature 426(6965):450-454. https:// doi.org/10.1038/nature02145

Li YC, Bai WZ, Hashikawa T (2020c) The neuroinvasive potential of SARS-CoV2 may play a role in the respiratory failure of COVID-19 patients. J Med Virol 92(6):552-555. https://doi. org/10.1002/jmv.25728

Li YC, Bai WZ, Hirano N, Hayashida T, Taniguchi T, Sugita Y, Tohyama K, Hashikawa T (2013) Neurotropic virus tracing suggests a membranous-coating-mediated mechanism for transsynaptic communication. J Comp Neurol 521(1):203-212. https://doi. org/10.1002/cne.23171

Liang B, Chen J, Li T, Wu H, Yang W, Li Y, Li J, Yu C, Nie F, Ma Z, Yang M, Xiao M, Nie P, Gao Y, Qian C, Hu M (2020) Clinical remission of a critically ill COVID-19 patient treated by human umbilical cord mesenchymal stem cells: a case report. Medicine (baltimore) 99(31):e21429. https://doi.org/10.1097/ MD.0000000000021429

Lisboa Bastos M, Tavaziva G, Abidi SK, Campbell JR, Haraoui LP, Johnston JC, Lan Z, Law S, MacLean E, Trajman A, Menzies D, Benedetti A, Ahmad Khan F (2020) Diagnostic accuracy of serological tests for covid-19: systematic review and metaanalysis. BMJ 370:m2516. https://doi.org/10.1136/bmj.m2516

Liu C, Zhou Q, Li Y, Garner LV, Watkins SP, Carter LJ, Smoot J, Gregg AC, Daniels AD, Jervey S, Albaiu D (2020a) Research and development on therapeutic agents and vaccines for COVID19 and related human coronavirus diseases. ACS Cent Sci 6(3):315-331. https://doi.org/10.1021/acscentsci.0c00272

Liu J, Zheng X, Tong Q, Li W, Wang B, Sutter K, Trilling M, Lu M, Dittmer U, Yang D (2020b) Overlapping and discrete aspects of the pathology and pathogenesis of the emerging human pathogenic coronaviruses SARS-CoV, MERS-CoV, and 2019-nCoV. J Med Virol 92(5):491-494. https://doi.org/10.1002/jmv.25709

Liu K, Mori S, Takahashi HK, Tomono Y, Wake H, Kanke T, Sato Y, Hiraga N, Adachi N, Yoshino T, Nishibori M (2007) Antihigh mobility group box 1 monoclonal antibody ameliorates brain infarction induced by transient ischemia in rats. FASEB $\mathrm{J}$ 21(14):3904-3916. https://doi.org/10.1096/fj.07-8770com

Liu Y, Gayle AA, Wilder-Smith A, Rocklöv J (2020) The reproductive number of COVID-19 is higher compared to SARS coronavirus. J Travel Med 27(2):taaa021. https://doi.org/10.1093/jtm/taaa021

Liu Z, Xiao X, Wei X, Li J, Yang J, Tan H, Zhu J, Zhang Q, Wu J, Liu L (2020d) Composition and divergence of coronavirus spike proteins and host ACE2 receptors predict potential intermediate hosts of SARS-CoV-2. J Med Virol 92(6):595-601. https://doi. org/10.1002/jmv. 25726

Lopez-Leon S, Wegman-Ostrosky T, Perelman C, Sepulveda R, Rebolledo PA, Cuapio A, Villapol S (2021) More than 50 long-term effects of COVID-19: a systematic review and metaanalysis. medRxiv [Preprint] https://doi.org/10.1101/2021.01. 27.21250617

Lu R, Zhao X, Li J, Niu P, Yang B, Wu H, Wang W, Song H, Huang B, Zhu N, Bi Y, Ma X, Zhan F, Wang L, Hu T, Zhou H, Hu Z, Zhou W, Zhao L, Chen J, Meng Y, Wang J, Lin Y, Yuan J, Xie Z, Ma J, Liu WJ, Wang D, Xu W, Holmes EC, Gao GF, Wu G, Chen W, Shi W, Tan W (2020a) Genomic characterisation and epidemiology of 2019 novel coronavirus: implications for virus origins and receptor binding. Lancet 395(10224):565-574. https://doi.org/10. 1016/S0140-6736(20)30251-8

Lu S, Wei N, Jiang J, Wu L, Sheng J, Zhou J, Fang Q, Chen Y, Zheng S, Chen F, Liang T, Hu S (2020b) First report of manic-like symptoms in a COVID-19 patient with no previous history of a psychiatric disorder. J Affect Disord 277:337-340. https://doi. org/10.1016/j.jad.2020.08.031

Luke TC, Kilbane EM, Jackson JL, Hoffman SL (2006) Meta-analysis: convalescent blood products for Spanish influenza pneumonia: a future H5N1 treatment? Ann Intern Med 145(8):599-609. https:// doi.org/10.7326/0003-4819-145-8-200610170-00139

Mao L, Jin H, Wang M, Hu Y, Chen S, He Q, Chang J, Hong C, Zhou Y, Wang D, Miao X, Li Y, Hu B (2020) Neurologic manifestations of hospitalized patients with coronavirus disease 2019 in Wuhan. China JAMA Neurol 77(6):683-690. https://doi.org/10. 1001/jamaneurol.2020.1127

Marano G, Vaglio S, Pupella S, Facco G, Catalano L, Liumbruno GM, Grazzini G (2016) Convalescent plasma: new evidence for an old therapeutic tool? Blood Transfus 14(2):152-157. https://doi.org/ 10.2450/2015.0131-15

Marote A, Teixeira FG, Mendes-Pinheiro B, Salgado AJ (2016) MSCsderived exosomes: cell-secreted nanovesicles with regenerative potential. Front Pharmacol 7:231

Marquez-Curtis LA, Janowska-Wieczorek A, McGann LE, Elliott JA (2015) Mesenchymal stromal cells derived from various tissues: biological, clinical and cryopreservation aspects. Cryobiology 71(2):181-197. https://doi.org/10.1016/j.cryobiol.2015.07.003

Mattern T, Scholz W, Feller AC, Flad HD, Ulmer AJ (1991) Expression of CD26 (dipeptidyl peptidase IV) on resting and activated human T-lymphocytes. Scand J Immunol 33(6):737-748. https:// doi.org/10.1111/j.1365-3083.1991.tb02548.x

McCray PB Jr, Pewe L, Wohlford-Lenane C, Hickey M, Manzel L, Shi L, Netland J, Jia HP, Halabi C, Sigmund CD, Meyerholz DK, Kirby P, Look DC, Perlman S (2007) Lethal infection of K18-hACE2 mice infected with severe acute respiratory syndrome coronavirus. J Virol 2:813-821. https://doi.org/10.1128/ JVI.02012-06

Meinhardt J, Radke J, Dittmayer C, Franz J, Thomas C, Mothes R, Laue M, Schneider J, Brünink S, Greuel S, Lehmann M, Hassan O, Aschman T, Schumann E, Chua RL, Conrad C, Eils R, Stenzel W, Windgassen M, Rößler L, Goebel HH, Gelderblom HR, Martin H, Nitsche A, Schulz-Schaeffer WJ, Hakroush S, Winkler MS, Tampe B, Scheibe F, Körtvélyessy P, Reinhold D, Siegmund B, Kühl AA, Elezkurtaj S, Horst D, Oesterhelweg L, Tsokos M, Ingold-Heppner B, Stadelmann C, Drosten C, Corman VM, Radbruch H, Heppner FL (2020) Olfactory transmucosal SARSCoV-2 invasion as a port of central nervous system entry in individuals with COVID-19. Nat Neurosci 24(2):168-175. https:// doi.org/10.1038/s41593-020-00758-5

Mendt M, Rezvani K, Shpall E (2019) Mesenchymal stem cell-derived exosomes for clinical use. Bone Marrow Transplant 54(Suppl 2):789-792

Meyerholz DK, Lambertz AM, McCray PB Jr (2016) Dipeptidyl peptidase 4 distribution in the human respiratory tract: implications for the middle east respiratory syndrome. Am J Pathol 186(1):78-86. https://doi.org/10.1016/j.ajpath.2015.09.014

Meyerowitz EA, Richterman A, Gandhi RT, Sax PE (2020) Transmission of SARS-CoV-2: a review of viral, host, and environmental factors. Ann Intern Med 17:M20-5008. https://doi.org/10.7326/ M20-5008

Moderna (2020) Moderna's COVID-19 vaccine candidate meets its primary efficacy endpoint in the first interim analysis of the phase 3 COVE study. Moderna, Inc. Available via : https://investors. modernatx.com/news-releases/news-release-details/modernascovid-19-vaccine-candidate-meets-its-primary-efficacy/. Accessed 18 Jan 2021

Moein ST, Hashemian SM, Mansourafshar B, Khorram-Tousi A, Tabarsi P, Doty RL (2020) Smell dysfunction: a biomarker for COVID-19. Int Forum Allergy Rhinol 10(8):944-950. https:// doi.org/10.1002/alr.22587 
National Center for Biotechnology Information (2020) Virus [cited 2020 Apr 8]. Available via: https://www.ncbi.nlm.nih.gov/labs/ virus/vssi/\#/virus?SeqType_s=Nucleotide $\&$ VirusLineage_ss= Severe \%20acute\%20respiratory\%20syndrome\%20coronavirus\% 202\%20(SARS-CoV-2),\%20taxid:2697049. Accessed April 8 2020

Netland J, Meyerholz DK, Moore S, Cassell M, Perlman S (2008) Severe acute respiratory syndrome coronavirus infection causes neuronal death in the absence of encephalitis in mice transgenic for human ACE2. J Virol 82(15):7264-7275. https://doi.org/10. 1128/JVI.00737-08

Nie Y, Wang G, Shi X, Zhang H, Qiu Y, He Z, Wang W, Lian G, Yin X, Du L, Ren L, Wang J, He X, Li T, Deng H, Ding M (2004) Neutralizing antibodies in patients with severe acute respiratory syndrome-associated coronavirus infection. J Infect Dis 190(6):1119-1126. https://doi.org/10.1086/423286

Nikolai LA, Meyer CG, Kremsner PG, Velavan TP (2020) Asymptomatic SARS coronavirus 2 infection: invisible yet invincible. Int J Infect Dis 100:112-116. https://doi.org/10.1016/j.ijid.2020. 08.076

Nishibori M, Mori S, Takahashi HK (2019) Anti-HMGB1 monoclonal antibody therapy for a wide range of CNS and PNS diseases. J Pharmacol Sci 140(1):94-101. https://doi.org/10.1016/j.jphs. 2019.04.006

Orooji Y, Sohrabi H, Hemmat N, Oroojalian F, Baradaran B, Mokhtarzadeh A, Mohaghegh M, Karimi-Maleh H (2021) An overview on SARS-CoV-2 (COVID-19) and other human coronaviruses and their detection capability via amplification assay, chemical sensing, biosensing, immunosensing, and clinical assays. Nanomicro Lett 13(1):18. https://doi.org/10.1007/ s40820-020-00533-y

Ou X, Liu Y, Lei X, Li P, Mi D, Ren L, Guo L, Guo R, Chen T, Hu J, Xiang Z, Mu Z, Chen X, Chen J, Hu K, Jin Q, Wang J, Qian Z (2020) Characterization of spike glycoprotein of SARSCoV-2 on virus entry and its immune cross-reactivity with SARS-CoV. Nat Commun 11(1):1620. https://doi.org/10.1038/ s41467-020-15562-9

Pal M, Berhanu G, Desalegn C, Kandi V (2020) Severe acute respiratory syndrome coronavirus-2 (SARS-CoV-2): an update. Cureus 12(3):e7423. https://doi.org/10.7759/cureus.7423

Panariello F, Cellini L, Speciani M, De Ronchi D, Atti AR (2020) How does SARS-CoV-2 affect the central nervous system? A Working Hypothesis Front Psychiatry 11:582345. https://doi.org/10.3389/ fpsyt.2020.582345

Perlman S, Netland J (2009) Coronaviruses post-SARS: update on replication and pathogenesis. Nat Rev Microbiol 7(6):439-450. https://doi.org/10.1038/nrmicro2147

Petersen MS, Kristiansen MF, Hanusson KD, Danielsen ME, Á Steig B, Gaini S, Strøm M, Weihe P (2020) Long COVID in the Faroe Islands - a longitudinal study among non-hospitalized patients. Clin Infect Dis 30:ciaa1792. https://doi.org/10.1093/cid/ciaa1792

Petrosillo N, Viceconte G, Ergonul O, Ippolito G, Petersen E (2020) COVID-19, SARS and MERS: are they closely related? Clin Microbiol Infect 26(6):729-734. https://doi.org/10.1016/j.cmi. 2020.03.026

Phinney DG, Pittenger MF (2017) Concise review: MSC-derived exosomes for cell-free therapy. Stem Cells 35(4):851-858. https://doi.org/10.1002/stem.2575

Pincha M, Sundarasetty BS, Stripecke R (2010) Lentiviral vectors for immunization: an inflammatory field. Expert Rev Vaccines 9(3):309-321. https://doi.org/10.1586/erv.10.9

Prabakaran P, Zhu Z, Xiao X, Biragyn A, Dimitrov AS, Broder CC, Dimitrov DS (2009) Potent human monoclonal antibodies against SARS CoV, Nipah and Hendra viruses. Expert Opin Biol Ther 9(3):355-368. https://doi.org/10.1517/ 14712590902763755
Prabhakar PK, Lakhanpal J (2020) Recent advances in the nucleic acid-based diagnostic tool for coronavirus. Mol Biol Rep 6:19. https://doi.org/10.1007/s11033-020-05889-3

Raj VS, Mou H, Smits SL, Dekkers DH, Müller MA, Dijkman R, Muth D, Demmers JA, Zaki A, Fouchier RA, Thiel V, Drosten C, Rottier PJ, Osterhaus AD, Bosch BJ, Haagmans BL (2013) Dipeptidyl peptidase 4 is a functional receptor for the emerging human coronavirus-EMC. Nature 495(7440):251-254. https://doi.org/ 10.1038/nature12005

Ramani A, Müller L, Ostermann PN, Gabriel E, Abida-Islam P, MüllerSchiffmann A, Mariappan A, Goureau O, Gruell H, Walker A, Andrée M, Hauka S, Houwaart T, Dilthey A, Wohlgemuth K, Omran H, Klein F, Wieczorek D, Adams O, Timm J, Korth C, Schaal H, Gopalakrishnan J (2020) SARS-CoV-2 targets neurons of 3D human brain organoids. EMBO J 39(20):e106230. https:// doi.org/10.15252/embj.2020106230

Reddy EK, Battula S, Anwar S, Sajith AM (2020) Drug re-purposing approach and potential therapeutic strategies to treat COVID-19. Mini Rev Med Chem 21(6):704-723. https://doi.org/10.2174/ 1389557520666201113105940

Richardson P, Griffin I, Tucker C, Smith D, Oechsle O, Phelan A, Rawling M, Savory E, Stebbing J (2020a) Baricitinib as potential treatment for 2019-nCoV acute respiratory disease. Lancet 395(10223):e30-e31. https://doi.org/10.1016/S0140-6736(20) 30304-4

Richardson PJ, Ottaviani S, Prelle A, Stebbing J, Casalini G, Corbellino M (2020b) CNS penetration of potential anti-COVID-19 drugs. J Neurol 267(7):1880-1882. https://doi.org/10.1007/ s00415-020-09866-5

Rodrigo C, Leonardi-Bee J, Nguyen-Van-Tam J, Lim WS (2016) Corticosteroids as adjunctive therapy in the treatment of influenza. Cochrane Database Syst Rev 3:CD010406. https://doi.org/10. 1002/14651858.CD010406.pub2

Russell B, Moss C, George G, Santaolalla A, Cope A, Papa S, Van Hemelrijck M (2020a) Associations between immune-suppressive and stimulating drugs and novel COVID-19-a systematic review of current evidence. Ecancermedicalscience 14:1022. https://doi.org/ 10.3332/ecancer.2020.1022

Russell B, Moss C, Rigg A, Van Hemelrijck M (2020b) COVID-19 and treatment with NSAIDs and corticosteroids: should we be limiting their use in the clinical setting? Ecancermedicalscience 14:1023. https://doi.org/10.3332/ecancer.2020.1023

Russell CD, Millar JE, Baillie JK (2020c) Clinical evidence does not support corticosteroid treatment for 2019-nCoV lung injury. Lancet 395(10223):473-475. https://doi.org/10.1016/S0140-6736(20) 30317-2

Salzberger B, Buder F, Lampl B, Ehrenstein B, Hitzenbichler F, Holzmann T, Schmidt B, Hanses F (2020) Epidemiology of SARS-CoV-2. Infection 8:1-7. https://doi.org/10.1007/ s15010-020-01531-3.

Samsonraj RM, Raghunath M, Nurcombe V, Hui JH, van Wijnen AJ, Cool SM (2017) Concise review: multifaceted characterization of human mesenchymal stem cells for use in regenerative medicine. Stem Cells Trans1 Med 6(12):2173-2185. https://doi.org/ $10.1002 /$ sctm.17-0129

Saponaro F, Rutigliano G, Sestito S, Bandini L, Storti B, Bizzarri R, Zucchi R (2020) ACE2 in the era of SARSCoV-2: controversies and novel perspectives. Front Mol Biosci 7:588618. https://doi. org/10.3389/fmolb.2020.588618

Sarwar Z, Ahmad T, Kakar S (2020) Potential approaches to combat COVID-19: a mini-review. Mol Biol Rep 47(12):9939-9949. https://doi.org/10.1007/s11033-020-05988-1

Seo Y, Kim HS, Hong IS (2019) Stem cell-derived extracellular vesicles as immunomodulatory therapeutics. Stem Cells Int 2019:5126156. https://doi.org/10.1155/2019/5126156 
Shanmugam C, Mohammed AR, Ravuri S, Luthra V, Rajagopal N, Karre S (2020) COVID-2019 - a comprehensive pathology insight. Pathol Res Pract 216(10):153222. https://doi.org/10. 1016/j.prp.2020.153222

Shen C, Wang Z, Zhao F, Yang Y, Li J, Yuan J, Wang F,Li D, Yang M, Xing L, Wei J, Xiao H, Yang Y, Qu J, Qing L, Chen L, Xu Z, PengL, Li Y, Zheng H, Chen F, Huang K, Jiang Y, Liu D, Zhang Z, Liu Y, Liu L (2020) Treatment of 5 critically ill patients with COVID-19 with convalescent plasma.JAMA 323(16):15821589. https://doi.org/10.1001/jama.2020.4783

Silva-Filho JC, Melo CGF, Oliveira JL (2020) The influence of ABO blood groups on COVID-19 susceptibility and severity: a molecular hypothesis based on carbohydrate-carbohydrate interactions. Med Hypotheses 144:110155. https://doi.org/10.1016/j.mehy. 2020.110155

Simorgh S, Alizadeh R, Eftekharzadeh M, Haramshahi SMA, Milan PB, Doshmanziari M, Ramezanpour F, Gholipourmalekabadi M, Seifi M, Moradi F (2019) Olfactory mucosa stem cells: an available candidate for the treatment of the Parkinson's disease. J Cell Physiol 234(12):23763-23773. https://doi.org/10.1002/jcp.28944

Singh S, Kumar NK, Dwiwedi P, Charan J, Kaur R, Sidhu P, Chugh VK (2018) Monoclonal antibodies: a review. Curr Clin Pharmacol 13(2):85-99. https://doi.org/10.2174/157488471266617 0809124728

Song E, Zhang C, Israelow B, Lu-Culligan A, Prado AV, Skriabine S, Lu P, Weizman OE, Liu F, Dai Y, Szigeti-Buck K, Yasumoto Y, Wang G, Castaldi C, Heltke J, Ng E, Wheeler J, Alfajaro MM, Levavasseur E, Fontes B, Ravindra NG, Van Dijk D, Mane S, Gunel M, Ring A, Kazmi SAJ, Zhang K, Wilen CB, Horvath TL, Plu I, Haik S, Thomas JL, Louvi A, Farhadian SF, Huttner A, Seilhean D, Renier N, Bilguvar K, Iwasaki A (2021) Neuroinvasion of SARS-CoV-2 in human and mouse brain. J Exp Med 218(3):e20202135. https://doi. org/10.1084/jem.20202135

Song X, Hu W, Yu H, Zhao L, Zhao Y, Zhao X, Xue HH, Zhao Y (2020) Little to no expression of angiotensin-converting enzyme- 2 on most human peripheral blood immune cells but highly expressed on tissue macrophages. Cytometry A. [Preprint] https://doi.org/10.1002/cyto.a.24285

Soo YO, Cheng Y, Wong R, Hui DS, Lee CK, Tsang KK, Ng MH, Chan P, Cheng G, Sung JJ (2004) Retrospective comparison of convalescent plasma with continuing high-dose methylprednisolone treatment in SARS patients. Clin Microbiol Infect 10(7):676678. https://doi.org/10.1111/j.1469-0691.2004.00956.x

Steiner DJ, Cognetti JS, Luta EP, Klose AM, Bucukovski J, Bryan MR, Schmuke JJ, Nguyen-Contant P, Sangster MY, Topham DJ, Miller BL (2020) Array-based analysis of SARS-CoV-2, other coronaviruses, and influenza antibodies in convalescent COVID19 patients. Biosens Bioelectron 169:112643. https://doi.org/10. 1016/j.bios.2020.112643

Su S, Wong G, Shi W, Liu J, Lai ACK, Zhou J, Liu W, Bi Y, Gao GF (2016) Epidemiology, genetic recombination, and pathogenesis of coronaviruses. Trends Microbiol 24(6):490-502. https://doi. org/10.1016/j.tim.2016.03.003

Sui J, Li W, Murakami A, Tamin A, Matthews LJ, Wong SK, Moore MJ, Tallarico AS, Olurinde M, Choe H, Anderson LJ, Bellini WJ, Farzan M, Marasco WA (2004) Potent neutralization of severe acute respiratory syndrome (SARS) coronavirus by a human $\mathrm{mAb}$ to $\mathrm{S} 1$ protein that blocks receptor association. Proc Natl Acad Sci USA 101(8):2536-2541. https://doi.org/10.1073/ pnas.0307140101

Takayama K (2020) In vitro and animal models for SARS-CoV-2 research. Trends Pharmacol Sci 41(8):513-517. https://doi.org/ 10.1016/j.tips.2020.05.005

Tang Y, Liu J, Zhang D, Xu Z, Ji J, Wen C (2020) Cytokine storm in COVID-19: the current evidence and treatment strategies.
Front Immunol 11:1708. https://doi.org/10.3389/fimmu.2020. 01708

Taylor W, Abbasi QH, Dashtipour K, Ansari S, Shah SA, Khalid A, Imran MA (2020) A review of the state of the art in noncontact sensing for COVID-19. Sensors (basel) 20(19):5665. https://doi.org/10.3390/s20195665

ter Meulen J, van den Brink EN, Poon LL, Marissen WE, Leung CS, Cox F, Cheung CY, Bakker AQ, Bogaards JA, van Deventer E, Preiser W, Doerr HW, Chow VT, de Kruif J, Peiris JS, Goudsmit J (2006) Human monoclonal antibody combination against SARS coronavirus: synergy and coverage of escape mutants. PLoS Med 3(7):e237. https://doi.org/10.1371/journal.pmed.0030237

Tian S, Hu W, Niu L, Liu H, Xu H, Xiao SY (2020) Pulmonary pathology of early-phase 2019 novel coronavirus (COVID-19) pneumonia in two patients with lung cancer. J Thorac Oncol 15(5):700704. https://doi.org/10.1016/j.jtho.2020.02.010

To KF, Tong JH, Chan PK, Au FW, Chim SS, Chan KC, Cheung JL, Liu EY, Tse GM, Lo AW, Lo YM, Ng HK (2004) Tissue and cellular tropism of the coronavirus associated with severe acute respiratory syndrome: an in-situ hybridization study of fatal cases. J Pathol 202(2):157-163. https://doi.org/10.1002/path.1510

Tokunaga R, Zhang W, Naseem M, Puccini A, Berger MD, Soni S, McSkane M, Baba H, Lenz HJ (2018) CXCL9, CXCL10, CXCL11/CXCR3 axis for immune activation - a target for novel cancer therapy. Cancer Treat Rev 63:40-47. https://doi.org/10. 1016/j.ctrv.2017.11.007

Touret F, de Lamballerie X (2020) Of chloroquine and COVID-19. Antiviral Res 177:104762. https://doi.org/10.1016/j.antiviral. 2020.104762

Trounson A, McDonald C (2015) Stem cell therapies in clinical trials: progress and challenges. Cell Stem Cell 17(1):11-22. https://doi. org/10.1016/j.stem.2015.06.007

Tu TM, Goh C, Tan YK, Leow AS, Pang YZ, Chien J, Shafi H, Chan BP, Hui A, Koh J, Tan BY, Umapathi NT, Yeo LL (2020) Cerebral venous thrombosis in patients with COVID-19 infection: a case series and systematic review. J Stroke Cerebrovasc Dis 29(12):105379. https://doi.org/10.1016/j.jstrokecerebrovasdis. 2020.105379

Udugama B, Kadhiresan P, Kozlowski HN, Malekjahani A, Osborne M, Li VYC, Chen H, Mubareka S, Gubbay JB, Chan WCW (2020) Diagnosing COVID-19: the disease and tools for detection. ACS Nano 14(4):3822-3835. https://doi.org/10.1021/ acsnano.0c02624

Uhal BD, Li X, Xue A, Gao X, Abdul-Hafez A (2011) Regulation of alveolar epithelial cell survival by the ACE-2/angiotensin 1-7/ Mas axis. Am J Physiol Lung Cell Mol Physiol 301(3):L269L274. https://doi.org/10.1152/ajplung.00222.2010

van den Brink EN, Ter Meulen J, Cox F, Jongeneelen MA, Thijsse A, Throsby M, Marissen WE, Rood PM, Bakker AB, Gelderblom HR, Martina BE, Osterhaus AD, Preiser W, Doerr HW, de Kruif J, Goudsmit J (2005) Molecular and biological characterization of human monoclonal antibodies binding to the spike and nucleocapsid proteins of severe acute respiratory syndrome coronavirus. J Virol 79(3):1635-1644. https://doi.org/10.1128/JVI.79.3. 1635-1644.2005

V'kovski P, Kratzel A, Steiner S, Stalder H, Thiel V, (2021) Coronavirus biology and replication: implications for SARS-CoV-2. Nat Rev Microbiol 19(3):155-170. https://doi.org/10.1038/ s41579-020-00468-6

Volarevic V, Gazdic M, Simovic Markovic B, Jovicic N, Djonov V, Arsenijevic N (2017) Mesenchymal stem cell-derived factors: immuno-modulatory effects and therapeutic potential. BioFactors 43(5):633-644. https://doi.org/10.1002/biof.1374

Vos ERA, den Hartog G, Schepp RM, Kaaijk P, van Vliet J, Helm K, Smits G, Wijmenga-Monsuur A, Verberk JDM, van Boven M, van Binnendijk RS, de Melker HE, Mollema L, van der Klis FRM 
(2020) Nationwide seroprevalence of SARS-CoV-2 and identification of risk factors in the general population of the Netherlands during the first epidemic wave. J Epidemiol Community Health 75(6):489-495. https://doi.org/10.1136/jech-2020-215678

Walls AC, Park YJ, Tortorici MA, Wall A, McGuire AT, Veesler D (2020) Structure, function, and antigenicity of the SARS-CoV-2 spike glycoprotein. Cell 181(2):281-292.e6. https://doi.org/10. 1016/j.cell.2020.02.058

Walsh EE, Frenck R, Falsey AR, Kitchin N, Absalon J, Gurtman A, Lockhart S, Neuzil K, Mulligan MJ, Bailey R, Swanson KA, Li P, Koury K, Kalina W, Cooper D, Fontes-Garfias C, Shi PY, Türeci Ö, Thompkins KR, Lyke KE, Raabe V, Dormitzer PR, Jansen KU, Sahin U, Gruber WC (2020) RNA-based COVID-19 vaccine BNT162b2 selected for a pivotal efficacy study. medRxiv 08(17)20176651. https://doi.org/10.1101/2020.08.17.20176651. Update in: N Engl J Med. 2020

Wang C, Li W, Drabek D, Okba NMA, van Haperen R, Osterhaus ADME, van Kuppeveld FJM, Haagmans BL, Grosveld F, Bosch BJ (2020a) A human monoclonal antibody blocking SARSCoV-2 infection. Nat Commun 11(1):2251. https://doi.org/10. 1038/s41467-020-16256-y

Wang D, Liu K, Wake H, Teshigawara K, Mori S, Nishibori M (2017) Anti-high mobility group box-1 (HMGB1) antibody inhibits hemorrhage-induced brain injury and improved neurological deficits in rats. Sci Rep 7:46243. https://doi.org/10.1038/srep46243

Wang M, Cao R, Zhang L, Yang X, Liu J, Xu M, Shi Z, Hu Z, Zhong W, Xiao G (2020b) Remdesivir and chloroquine effectively inhibit the recently emerged novel coronavirus (2019-nCoV) in vitro. Cell Res 30(3):269-271. https://doi.org/10.1038/ s41422-020-0282-0

Wang K, Chen W, Zhang Z, Deng Y, Lian JQ, Du P, Wei D, Zhang Y, Sun XX, Gong L, Yang X, He L, Zhang L, Yang Z, Geng JJ, Chen R, Zhang H, Wang B, Zhu YM, Nan G, Jiang JL, Li L, Wu J, Lin P, Huang W, Xie L, Zheng ZH, Zhang K, Miao JL, Cui HY, Huang M, Zhang J, Fu L, Yang XM, Zhao Z, Sun S, Gu H, Wang Z, Wang CF, Lu Y, Liu YY, Wang QY, Bian H, Zhu P, Chen ZN (2020c) CD147-spike protein is a novel route for SARS-CoV-2 infection to host cells. Signal Transduct Target Ther 5(1):283. https://doi.org/10.1038/s41392-020-00426-x

Wang WY, Tan MS, Yu JT, Tan L (2015) Role of pro-inflammatory cytokines released from microglia in Alzheimer's disease. Ann Transl Med 3(10):136. https://doi.org/10.3978/j.issn.2305-5839. 2015.03.49

Wang X, Lazorchak AS, Song L, Li E, Zhang Z, Jiang B, Xu RH (2016b) Immune modulatory mesenchymal stem cells derived from human embryonic stem cells through a trophoblast-like stage. Stem Cells 34(2):380-391. https://doi.org/10.1002/stem. 2242

Weiss ARR, Dahlke MH (2019) Immunomodulation by mesenchymal stem cells (MSCs): mechanisms of action of living, apoptotic, and dead MSCs. Front Immunol 10:1191. https://doi.org/10. 3389/fimmu.2019.01191

Weiss SR, Leibowitz JL (2011) Coronavirus pathogenesis. Adv Virus Res 81:85-164. https://doi.org/10.1016/B978-0-12-385885-6. 00009-2

Weissleder R, Lee H, Ko J, Pittet MJ (2020) COVID-19 diagnostics in context. Sci Transl Med 12(546):eabc1931. https://doi.org/10. 1126/scitranslmed.abc1931

Wichmann D, Sperhake JP, Lütgehetmann M, Steurer S, Edler C, Heinemann A, Heinrich F, Mushumba H, Kniep I, Schröder AS, Burdelski C, de Heer G, Nierhaus A, Frings D, Pfefferle $\mathrm{S}$, Becker H, Bredereke-Wiedling $\mathrm{H}$, de Weerth A, Paschen HR, Sheikhzadeh-Eggers S, Stang A, Schmiedel S, Bokemeyer C, Addo MM, Aepfelbacher M, Püschel K, Kluge S (2020) Autopsy dfindings and venous thromboembolism in patients with COVID-19: a prospective cohort study. Ann Intern Med 173(4):268-277. https://doi.org/10.7326/M20-2003

Widagdo W, Sooksawasdi Na Ayudhya S, Hundie GB, Haagmans BL (2019) Host determinants of MERS-CoV transmission and pathogenesis. Viruses 3:280. https://doi.org/10.3390/v11030280

Wiener RS, Cao YX, Hinds A, Ramirez MI, Williams MC (2007) Angiotensin converting enzyme 2 is primarily epithelial and is developmentally regulated in the mouse lung. J Cell Biochem 101(5):1278-1291. https://doi.org/10.1002/jcb.21248

Willman M, Kobasa D, Kindrachuk J (2019) A comparative analysis of factors influencing two outbreaks of middle eastern respiratory syndrome (MERS) in Saudi Arabia and South Korea. Viruses 11(12):1119. https://doi.org/10.3390/v11121119

Wilson JJ, Foyle KL, Foeng J, Norton T, McKenzie DR, Payne N, Bernard CC, McColl SR, Comerford I (2018) Redirecting adult mesenchymal stromal cells to the brain: a new approach for treating CNS autoimmunity and neuroinflammation? Immunol Cell Biol 96(4):347-357. https://doi.org/10.1111/imcb.12014

Wölfel R, Corman VM, Guggemos W, Seilmaier M, Zange S, Müller MA, Niemeyer D, Jones TC, Vollmar P, Rothe C, Hoelscher M, Bleiker T, Brünink S, Schneider J, Ehmann R, Zwirglmaier K, Drosten C, Wendtner C (2020) Virological assessment of hospitalized patients with COVID-2019. Nature 581:465-469. https:// doi.org/10.1038/s41586-020-2196-x

Wolff D, Nee S, Hickey NS, Marschollek M (2020) Risk factors for Covid-19 severity and fatality: a structured literature review. Infection 28:1-14. https://doi.org/10.1007/s15010-020-01509-1

World Health Organization (2020a) Coronavirus disease 2019. In: Coronavirus disease (COVID-19) pandemic. Available from https://www.who.int/emergencies/diseases/novel-coronavirus2019. Accessed April 82020

World Health Organization (2020b) Summary table of available protocols in this document. In: Who In House Assays. In: Overview. Available from https://www.who.int/docs/default-source/ coronaviruse/whoinhouseassays.pdf?sfvrsn=de3a76aa_2. Accessed December 152020

World Health Organization (2021) WHO coronavirus disease (COVID19) dashboard. In: Overview. Available from https://covid19. who.int/. Accessed May 52021

Wrapp D, Wang N, Corbett KS, Goldsmith JA, Hsieh CL, Abiona O, Graham BS, McLellan JS (2020) Cryo-EM structure of the 2019-nCoV spike in the prefusion conformation. Science 367(6483):1260-1263. https://doi.org/10.1126/science.abb2507

Wu F, Zhao S, Yu B, Chen Y-M, Wang W, Hu Y, Song Z-G, Tao Z-W, Tian J-H, Pei Y-Y, Yuan M-L, Zhang Y-L, Dai F-H, Liu Y, Wang Q-M, Zheng J-J, Xu L, Holmes EC, Zhang Y-Z (2020) Complete genome characterisation of a novel coronavirus associated with severe human respiratory disease in Wuhan, China. Pathology. Available from: http://biorxiv.org/lookup/doi/10.1101/2020.01. 24.919183. Accessed April 82020

Xiong Y, Liu Y, Cao L, Wang D, Guo M, Jiang A, Guo D, Hu W, Yang J, Tang Z, Wu H, Lin Y, Zhang M, Zhang Q, Shi M, Liu Y, Zhou Y, Lan K, Chen Y (2020) Transcriptomic characteristics of bronchoalveolar lavage fluid and peripheral blood mononuclear cells in COVID-19 patients. Emerg Microbes Infect 9(1):761-770. https://doi.org/10.1080/22221751.2020.1747363

Xu H, Zhong L, Deng J, Peng J, Dan H, Zeng X, Li T, Chen Q (2020a) High expression of ACE2 receptor of 2019-nCoV on the epithelial cells of oral mucosa. Int J Oral Sci 12(1):8. https://doi.org/ 10.1038/s41368-020-0074-X

Xu J, Yang J, Chen J, Luo Q, Zhang Q, Zhang H (2017) Vitamin D alleviates lipopolysaccharide-induced acute lung injury via regulation of the renin-angiotensin system. Mol Med Rep 16(5):74327438. https://doi.org/10.3892/mmr.2017.7546 
Xu J, Zhong S, Liu J, Li L, Li Y, Wu X, Li Z, Deng P, Zhang J, Zhong N, Ding Y, Jiang Y (2005) Detection of severe acute respiratory syndrome coronavirus in the brain: potential role of the chemokine mig in pathogenesis. Clin Infect Dis 41(8):10891096. https://doi.org/10.1086/444461

Xu X, Han M, Li T, Sun W, Wang D, Fu B, Zhou Y, Zheng X, Yang Y, Li X, Zhang X, Pan A, Wei H (2020) Effective treatment of severe COVID-19 patients with tocilizumab. Proc Natl Acad Sci USA 117(20):10970-10975. https://doi.org/10.1073/pnas. 2005615117

Yan CH, Faraji F, Prajapati DP, Ostrander BT, DeConde AS (2020) Self-reported olfactory loss associates with outpatient clinical course in COVID-19. Int Forum Allergy Rhinol 10(7):821-831. https://doi.org/10.1002/alr.22592

Yoshikawa R, Abe H, Igasaki Y, Negishi S, Goto H, Yasuda J (2020) Development and evaluation of a rapid and simple diagnostic assay for COVID-19 based on loop-mediated isothermal amplification. PLoS Negl Trop Dis 14(11):e0008855. https://doi.org/ 10.1371/journal.pntd.0008855

Zhang C, Maruggi G, Shan H, Li J (2019) Advances in mRNA vaccines for infectious diseases. Front Immunol 10:594. https://doi.org/10. 3389/fimmu.2019.00594

Zhang C, Wu Z, Li JW, Zhao H, Wang GQ (2020a) Cytokine release syndrome in severe COVID-19: interleukin-6 receptor antagonist tocilizumab may be the key to reduce mortality. Int J Antimicrob Agents 55(5):105954. https://doi.org/10.1016/j.ijantimicag.2020. 105954

Zhang H, Penninger JM, Li Y, Zhong N, Slutsky AS (2020b) Angiotensin-converting enzyme 2 (ACE2) as a SARS-CoV-2 receptor: molecular mechanisms and potential therapeutic target. Intensive Care Med 46(4):586-590. https://doi.org/10.1007/ s00134-020-05985-9

Zhang J, Takahashi HK, Liu K, Wake H, Liu R, Maruo T, Date I, Yoshino T, Ohtsuka A, Mori S, Nishibori M (2011) Anti-high mobility group box-1 monoclonal antibody protects the bloodbrain barrier from ischemia-induced disruption in rats. Stroke 42(5):1420-1428. https://doi.org/10.1161/STROKEAHA.110. 598334D

Zhang L, Pang R, Xue X, Bao J, Ye S, Dai Y, Zheng Y, Fu Q, Hu Z, Yi Y (2020c) Anti-SARS-CoV-2 virus antibody levels in convalescent plasma of six donors who have recovered from COVID-19. Aging (albany NY) 12(8):6536-6542. https://doi. org/10.18632/aging.103102

Zhang Y, Geng X, Tan Y, Li Q, Xu C, Xu J, Hao L, Zeng Z, Luo X, Liu F, Wang H (2020d) New understanding of the damage of
SARS-CoV-2 infection outside the respiratory system. Biomed Pharmacother 127:110195. https://doi.org/10.1016/j.biopha. 2020.110195

Zhao J, Cui W, Tian B-p (2020) The potential intermediate hosts for SARS-CoV-2. Front Microbiol 11:580137. https://doi.org/10. 3389/fmicb.2020.580137

Zhou G, Zhao Q (2020) Perspectives on therapeutic neutralizing antibodies against the Novel Coronavirus SARS-CoV-2. Int J Biol Sci 16(10):1718-1723. https://doi.org/10.7150/ijbs.45123

Zhou H, Fang Y, Xu T, Ni WJ, Shen AZ, Meng XM (2020a) Potential therapeutic targets and promising drugs for combating SARSCoV-2. Br J Pharmacol 177(14):3147-3161. https://doi.org/10. 1111/bph.15092

Zhou P, Yang XL, Wang XG, Hu B, Zhang L, Zhang W, Si HR, Zhu Y, Li B, Huang CL, Chen HD, Chen J, Luo Y, Guo H, Jiang RD, Liu MQ, Chen Y, Shen XR, Wang X, Zheng XS, Zhao K, Chen QJ, Deng F, Liu LL, Yan B, Zhan FX, Wang YY, Xiao GF, Shi ZL (2020b) A pneumonia outbreak associated with a new coronavirus of probable bat origin. Nature 579(7798):270-273. https://doi.org/10.1038/s41586-020-2012-7

Zhou Y, Ghassemi P, Chen M, McBride D, Casamento JP, Pfefer TJ, Wang Q (2020c) Clinical evaluation of fever-screening thermography: impact of consensus guidelines and facial measurement location. J Biomed Opt 25(9):097002. https://doi.org/10.1117/1. JBO.25.9.097002

Zhu H, Xiong Y, Xia Y, Zhang R, Tian D, Wang T, Dai J, Wang L, Yao H, Jiang H, Yang K, Liu E, Shi Y, Fu Z, Gao L, Zou L (2017) Therapeutic effects of human umbilical cord-derived mesenchymal stem cells in acute lung injury mice. Sci Rep 7:39889

Zou L, Ruan F, Huang M, Liang L, Huang H, Hong Z, Yu J, Kang M, Song Y, Xia J, Guo Q, Song T, He J, Yen HL, Peiris M, Wu J (2020a) SARS-CoV-2 viral load in upper respiratory specimens of infected patients. N Engl J Med 382(12):1177-1179. https:// doi.org/10.1056/NEJMc2001737

Zou X, Chen K, Zou J, Han P, Hao J, Han Z (2020b) Single-cell RNAseq data analysis on the receptor ACE2 expression reveals the potential risk of different human organs vulnerable to 2019nCoV infection. Front Med 14(2):185-192. https://doi.org/10. 1007/s11684-020-0754-0

Publisher's Note Springer Nature remains neutral with regard to jurisdictional claims in published maps and institutional affiliations. 